\title{
Türkiye'deki Büyükşehirlerin Karayolu Ulaşımı Kaynaklı Sera Gazı Emisyon Miktarının Karşılaştırmalı Analizi
}

\author{
Abdullah Oktay Dündar ${ }^{1, *}$ \\ ${ }^{1}$ Necmettin Erbakan Üniversitesi, Uygulamalı Bilimler Fakültesi, Lojistik Yönetimi Bölümü, 42090, Konya. \\ Özet
}

Bu çalışmada Türkiye'deki büyükşehirlerin 2010 ve 2019 yıllarına ait karayolu ulaşımından (bireysel seyahatler+yolcu ve yük taşımacılığı) kaynaklı sera gazı emisyon miktarları IPCC tarafindan geliş̧tirilen Tier 1 yöntemi kullanılarak hesaplanmıştır. Elde edilen sonuçlara göre 30 büyükşehirde 2010 yılında toplam sera gazı emisyon miktarı 43.403 Gg $\mathrm{CO}_{2}$ eşdeğer(e.) iken, 2019 yllında artarak $70.271 \mathrm{Gg} \mathrm{CO}_{2}$ e. ulaşmıştır. 2010-2019 yılları arasında toplam sera gazı emisyon miktarı \%61,90 oranında artış göstermiştir. Toplam sera gazı emisyon miktarında İstanbul, Ankara, İzmir, kiși bașına düșen sera gazı emisyon miktarında Denizli, Mersin, Muğla, araç başına düşen sera gazı emisyon miktarında Mardin, Kocaeli, Diyarbakır, $\mathrm{km}^{2}$ 'ye düșen sera gazı emisyon miktarında ise İstanbul, Kocaeli, İzmir sehirleri ilk 3 sirada yer almaktadir. Hem 2010 hem de 2019 yılında İstanbul, Ankara, Izmir, Bursa, Mersin, Antalya, Konya ve Kocaeli ortalama emisyon miktarının üstünde değerlere sahiptir. Bu şehirlerde alınacak öncelikli önlemler ile ülkemizin karayolu kaynaklı emisyon miktarı önemli oranda düşürülebilecektir. Diğer taraftan Mardin, Van ve Şanlıurfa gibi doğu bölgemizdeki şehirlerde emisyon artış hızı diğer şehirlere göre çok daha yüksektir. Çalışmada büyükşehirler alternatif taşıma seçenekleri ve alt yapılara göre de karşılaştırılmış ve demiryolu hariç diğer seçeneklerin emisyon artış hızını azaltmada etkili olduğu tespit edilmiştir

\section{$\underline{\text { Anahtar Sözcükler }}$}

Karayolu Ulaşımı, Yeşil Lojistik, Büyükşehirler, Sürdürülebilirlik, Sera Gazı Emisyonu, Tier 1

\section{Comparative Analysis of the Greenhouse Gas Emissions from Road Transport in The Metropolitan Cities of Turkey}

\begin{abstract}
In this study, the amount of greenhouse gas emissions from road transport belonging to the metropolis in Turkey in 2010 and 2019 were calculated using the Tier 1 method developed by the IPCC. According to the results, while the total amount of greenhouse gas emissions in 30 metropolitan cities in 2010 was 43,403 $\mathrm{Gg} \mathrm{CO}_{2}$ equivalent, it increased in 2019 and reached 70, $271 \mathrm{Gg} \mathrm{CO}_{2}$ equivalent. Between 2010 and 2019, the total amount of greenhouse gas emissions increased by 61.90\%. The cities of Istanbul, Ankara, Izmir in total greenhouse gas emissions, Denizli, Mersin, Muğla in terms of greenhouse gas emissions per capita, Mardin, Kocaeli, Diyarbakır in terms of greenhouse gas emissions per vehicle, and Istanbul, Kocaeli and İzmir in terms of greenhouse gas emissions per km². are in the top 3 places. Both in 2010 and 2019, Istanbul, Ankara, Izmir, Bursa, Mersin, Antalya, Konya and Kocaeli have values above the average emission amount. With priority measures to be taken in these cities, the total amount of emissions in our country can be reduced significantly. On the other hand, in cities in our eastern region such as Mardin, Van and Şanliurfa, the speed of increase in emissions is much higher than that of other cities. In the study, metropolitan cities were compared according to alternative transportation options and infrastructures and it was determined that other options, except rail, were effective in reducing the emission rate.
\end{abstract}

\section{$\underline{\text { Keywords }}$}

Road Transportation, Green Logistics, Metropolitan Cities, Sustainability, Greenhouse Gas Emission, Tier 1

\section{Giriş}

İnsan faaliyetleri sonucu sera etkisinin kuvvetlenmesi, dünya sıcaklığını her geçen gün artırmakta ve küresel ısınmaya sebep olmaktadır. Küresel ısınma eko sistemin bozulmasına ve beklenmeyen doğa olaylarına sebep olarak kuraklık ve aşırı yağışlar sonucu insan hayatını olumsuz yönde etkilemektedir. Hükümetler Arası İklim Değişikliği Paneli (IPCC) tarafından 1970-2010 yıllarını içeren hesaplamaya göre toplam sera gazı emisyonu; \%76 karbon dioksit $\left(\mathrm{CO}_{2}\right)$, \%16 metan $\left(\mathrm{CH}_{4}\right)$, \%6,2 diazotoksit $\left(\mathrm{N}_{2} \mathrm{O}\right)$ ve \%2 oranında florlu gazlarından oluşmaktadır (IPCC 2014). $\mathrm{CO}_{2}$ 'in başlıca kaynağı fosil yakıt kullanımıdır. Fosil yakıt kullanımı sanayide üretim, evlerde ısınma ve taşımacılık faaliyetlerinde yoğun olarak gerçekleşmektedir. Bu sektörlerden kaynakl $\mathrm{CO}_{2}$ oranı \%65'tir. Diğer taraftan tarım faaliyetleri için ormanların yok edilmesi ve toprağın bozulması da $\mathrm{CO}_{2}$ artışında önemli rol oynamakta ve toplam içinde \%11 oranında yer almaktadır (Edenhofer 2015). 
$\mathrm{CH}_{4}$ gazı ise tarım, enerji ihtiyacının karşılanması ve atık yönetimi gibi faaliyetler sonucu açı̆̆a çıkmaktadır. $\mathrm{N}_{2} \mathrm{O}$ ’nun birincil kaynağı tarımda kullanılan gübrelemedir. Fosil yakıt kullanımı da $\mathrm{N}_{2} \mathrm{O}$ salınımına sebep olmaktadır (EPA 2019). 2016 yılında ise İklim Saati (Climate Watch) verilerine göre $\mathrm{CO}_{2}$ emisyon oranlarında önemli azalışlar meydana gelmiş ve toplam sera gazı emisyonundaki $\mathrm{CO}_{2}$ payı \%74,3'e düşmüştür (Climate Watch 2020). 2016 y1lı sera gazı emisyonlarının sektörlere ve son kullanım faaliyetlerine göre dağılımı Şekil 1'de gösterilmiştir.

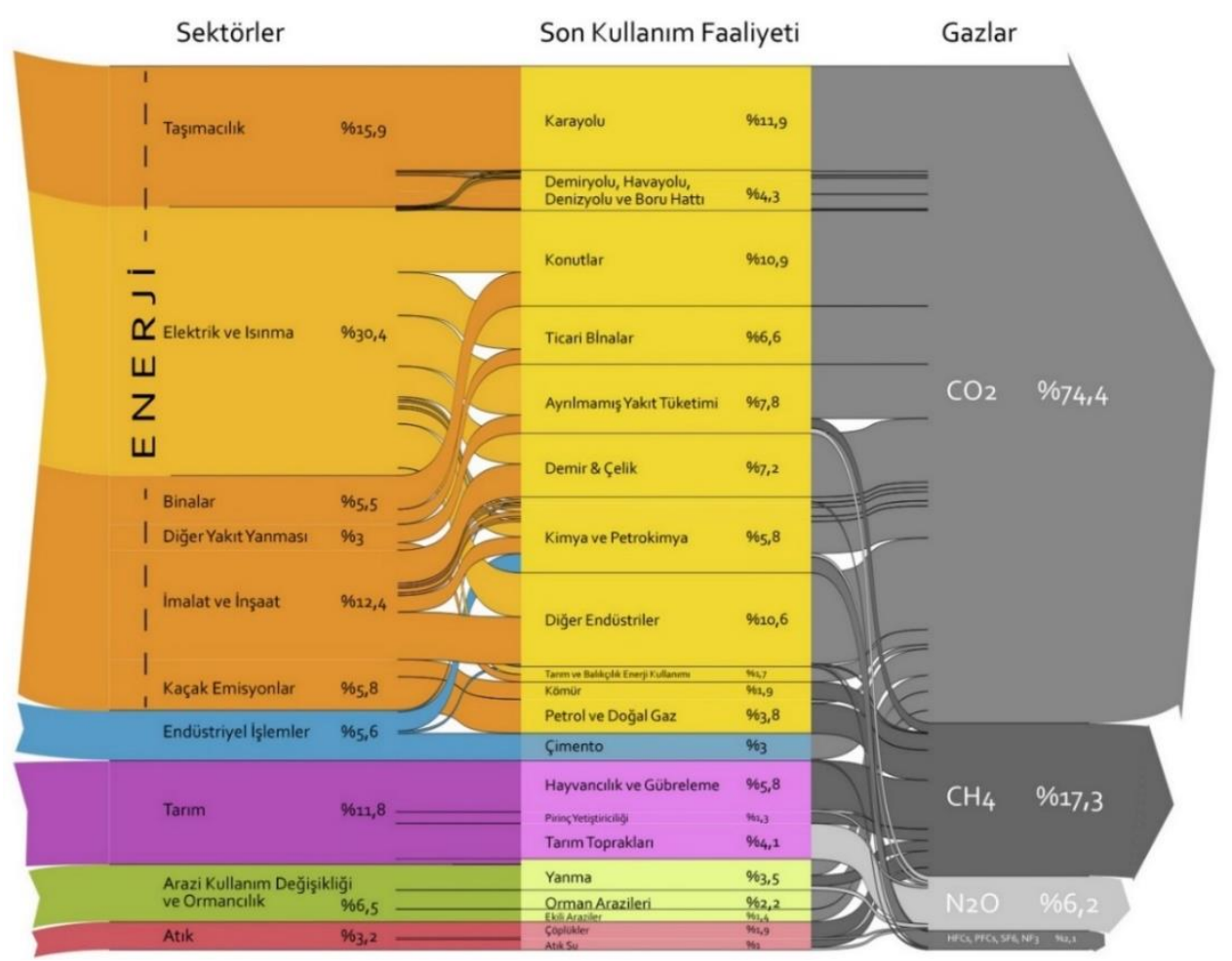

Şekil 1: 2016 Dünya Sera Gazı Emisyonları (https://www.climatewatchdata.org)

Şekil 1 incelendiğinde $\mathrm{CO}_{2}$ salınımının \%59 oranında enerji ihtiyacından kaynaklandığı görülmektedir. Sektörler incelendiğinde birinci sırada \%30,4 ile elektrik ve 1sınma ikinci sırada ise \%15,9 ile taşımacılık yer almaktadır. Son kullanım faaliyetlerine göre ise karayolu taşımacılığ $1 \% 11,9$ ile birinci sıradadır. Dolayısıyla karayolu taşımacılığı en önemli $\mathrm{CO}_{2}$ kaynaklarından biri olarak karşımıza çıkmaktadır.

Artan yolcu ve yük taşıma talebi taşımacılık sektörünün her geçen yıl sürekli büyümesine neden olmaktadır. Büyümeye paralel olarak sektörden kaynaklı $\mathrm{CO}_{2}$ emisyon miktarı da artmaktadır. Dolayısıyla etkili ve sürekli azaltma sağlayacak emisyon politikalarının uygulanması gerekmektedir. Eğer bu politikalar uygulanmaz ise emisyon salınımı diğer sektörlerden çok daha hızlı artarak 2050 yılında 12 Gt CO$C_{2}$ e./yıl'a ulaşabilecektir (Edenhofer 2015). Karayolundan kaynaklı sera gazı emisyonları motosiklet, otomobil, kamyon, kamyon+römork/çekici+yarı römork ve otobüslerde gerçekleşen benzin ve motorin (dizel) yakıtların yanması sonucu ortaya çıkmaktadır. Bu emisyonların \%60'1 yolcu seyahatleri ve taşımacılığından, kalan \%40’lık kısmı ise yük taşımacılığından kaynaklanmakta olup karbondan arındırılmış temiz enerjili karayolu araçlarının kullanılması ile küresel sera gazı emisyonları \%11,9 gibi büyük bir oranda azaltılabilecektir (Ritchie ve Roser 2017). Gelecek yıllarda AR-GE çalışmaları sonucu bu tür teknolojilerle donatılmış araçların piyasaya çıkması çevre ve halk sağlığı açısından faydalar sağlayacaktır (Mock 2016). Ancak mevcut araç stokunun kullanım ömrünü tamamlayıp yeni teknolojilere geçişin sağlanması uzun bir geçiş dönemini gerektirmektedir.

Karayolları kaynaklı sera gazı emisyonunun sürekli artmasına sebep olarak; artan araç sayısı, trafik sıkışıklığı, mevcut araçların emisyon miktarının çok olması, düzenli araç bakımlarının ve kirli gaz kontrolünün yapılmaması, yakıt kalitesinin düşük olması ve karayolları boyunca nüfus artışı gösterilmektedir (TÜSİAD 2007). Bu emisyonların azaltılması için yeni üretilen araçların yakıt verimliliğinin arttırılması, karayolu araçlarında emisyon miktarı daha düşük alternatif yakıtların kullanılması, trafik akışının düzenlenmesi, ulaşım planlamalarının yapılarak alternatif yaklaşımların geliştirilmesi önerilmektedir. Trafik akışını düzenleyen yeşil dalga uygulamaları ile sabit hızlarda seyreden araçların yakıt verimliliği artacak, trafik ışıklarının senkronizasyonu ile yakıt tüketimi azalacak ve emisyon miktarları düşürülebilecektir. Ulaşım planlaması ile raylı ulaşım payının artırılması ve aktarmalı seyahat imkanları sayesinde kapasite kullanım oranı artacak ve toplu ulaşımda yolcu başına düşen emisyon miktarı azaltılabilecektir. Ayrıca insanların bisiklet gibi emisyon sıfır alternatif taşıtları kullanması da bu noktada etkili olacaktır (Soruşbay 2007). Yukarıdaki önlemlere ilaveten emisyonun azaltılmasında yerel ürünlerin satın alınması, internetten alışveriş yapılması, lojistik sistemlerin yeniden yapılandırılması ve bilgi iletişim teknolojilerinin kullanımı ile mümkün olan yerlerde yolculuklardan kaçınılması önerilmektedir (Edenhofer 2015). 
Yük taşımacılığı karayolu kaynaklı emisyonların \%40’ını oluşturmaktadır. Bu sebeple yeşil lojistik yaklaşımlarının önemi her geçen gün artmaktadır. Yeşil lojistik, "çevrenin sahip olduğu özelliklerin lojistik operasyonlarla bütünleştirilmesi ve lojistik sistem boyunca bütün karar verme süreçlerinin çevreyi dikkate alarak yönetilmesidir” (Pishvaee vd. 2012). Bu noktada lojistik işletmeleri operasyonların çevreye verdiği zararı ölçmekte ve bu etkileri azaltmak amacıyla faaliyetler gerçekleştirmektedir. Yeşil lojistik kapsamında işletmeler, Euro 5 ve Euro 6 gibi standartlara sahip araçlar kullanmakta ve uzun mesafelerde karma taşımacılık (bir taşıma operasyonunda en az iki taşıma seçeneğinin birleştirilerek kullanılması) gerçekleştirmekte, güzergâhları optimize etmekte ve yük konsolidasyonu yaparak çevreye verdikleri zararı azaltmaya çalışmaktadır. Birçok lojistik işletmesi çevreye duyarlı olduklarını düzenli raporlar veya web sitelerinde karbon ayak izini yayınlayarak göstermektedir.

Mehrotra vd. (2011) kentsel ulaştırma sistemleri ve iklim değişikliği ilişkisini araştırmış ve şehirlerdeki emisyon miktarının büyük çoğunluğunun ulaşımın genişliğinden kaynaklandığını tespit etmişlerdir. Bireysel araç kullanımının yaygın ve ticari odak merkezi olmaları, şehirlerde fosil yakıt tüketimini arttırmaktadır. Fosil yakıtların \%95'i şehirlerde tüketilmekte ve karayolu kaynaklı emisyonlarının \%75’i şehirlerde gerçekleşmektedir (Mehrotra vd. 2011). Dolayısıyla şehirlerdeki emisyonlarının ölçülmesi ve azaltılması ile ilgili yapılacak çalışmalar toplam sera gazı emisyonlarının azaltılmasında önemli rol oynayacaktır.

Bu çalışmanın amacı, Türkiye'deki büyükşehirlerin karayolu kaynaklı sera gazı emisyon miktarını hesaplamak ve karşılaştırmalı analizini yapmaktır. Türkiye'deki büyükşehirler nüfus, araç sayıları ve ekonomik faaliyetlerin büyüklüğü bakımından önemli bir emisyon üreticisi konumundadır. Bu nedenle çalışmada 2019 yılında büyükşehir statüsüne sahip olan şehirler incelenmektedir. Çalışmada sera gazı emisyon hesaplamasında IPCC tarafından geliştirilen Tier 1 yöntemi ve EPDK tarafından yayınlanan büyükşehirlerin 2010 ve 2019 yıllarına ait yakıt satış verileri kullanılmıştır. Elde edilen sonuçlar CBS yazılımı ile Türkiye haritası üzerinde gösterilmiş ve karşılaştırmalı analizler yapılmıştır.

\section{Literatür İncelemesi}

Toplam sera gazı emisyonları içerisinde taşımacılık önemli bir paya sahiptir. Taşımacılıktan kaynaklı emisyonların büyük bir çoğunluğu ise karayolu taşımacılığından kaynaklanmaktadır. Bu sebeple literatürdeki taşımacılık kaynaklı sera gazı emisyonlarını inceleyen çalışmaların çoğunluğu karayolu ile ilgilidir. Son yıllarda ulusal literatürde de konuyla ilgili yapılan çalışmalarda bir artış olduğu görülmektedir. Aşağıda karayolu taşımacılığı ile ilgili yapılmış ulusal ve uluslararası literatürde yer alan bazı çalışmalara yer verilmiştir.

El-Fadel ve Bou-Zeid (1999) 1997 yılında Lübnan'daki karayolu taşımacılığı kaynaklı sera gazı emisyonlarını Tier 1 yöntemi ile hesaplamışlar ve 2020 yılındaki emisyon miktarını tahmin etmeye çalışmışlardır. Soruşbay (2007) karayolundan kaynaklı sera gazı emisyonlarının çevreye etkisini incelemiş ve emisyonların azaltılması için toplu taşımanın yaygınlaştırılması, alternatif taşıma modlarının kullanımı, eski teknolojili araçların yenileriyle değiştirilmesi gibi önerilerde bulunmuştur. Soylu (2007) 2004 yılı için Türkiye karayolu taşımacılığından kaynaklı sera gazı emisyonunu COPERT III programı kullanarak hesaplamıştır. Çalışmada $\mathrm{CO}_{2}, \mathrm{CH}_{4}, \mathrm{NO}_{2}, \mathrm{CO}, \mathrm{NMVOC} \mathrm{NO}_{\mathrm{x}}$ gazlarından kaynaklı sera gazı emisyonunun $51.368 \mathrm{CO}_{2} \mathrm{e}$. olduğu hesaplanmıştır. Otken ve Gümüşay (2010) coğrafik bilgi sistemi (CBS) kullanarak benzin ve motorin yakan araçlardan kaynaklı emisyonların miktarını, sıklığını ve emisyonun hangi durumlarda değiştiğini belirlemişlerdir. Çalışmada dizel araçların benzinli araçlara göre 2 kat daha fazla $\mathrm{CO}_{2} \mathrm{saln}_{1}$ gerçekleştirdiği belirlenmiştir. Liao vd. (2010) Tayvan'da karayoluyla gerçekleştirilen konteyner taşımacılığının neden olduğu sera gazı emisyon miktarını Tier 1 yöntemi ve regresyon modeli ile hesaplamıșlar, 1998-2008 yılları arasında emisyonunun \%89,3 arttığını belirtmişlerdir. Çevik ve Gülcan (2011) lojistik faaliyetlerin çevresel sürdürülebilirliğe etkilerini incelemiş ve Avrupa Birliği tarafından taşıma modları arasındaki dengenin ve lojistik sektöründe çevresel sürdürülebilirliğin sağlanması için geliştirilen Marco Polo projesinden bahsetmişlerdir. Kim vd., (2011) Kore’deki karayolu taşımacılığından kaynaklanan sera gazı emisyonlarını Tier 1, Tier 2 ve Tier 3 yöntemlerini kullanarak hesaplamışlar ve sonuçları karşılaştırmışlardır. Tier 3 yöntemi ile elde edilen sonuçların Tier 1'e göre \%10,1, Tier 2'ye göre \%20,7 daha düşük olduğu bildirilmiştir. Özen ve Tuydes-Yaman (2013) 2000-2009 yılları arasında yol kenarı aks araştırmalarını kullanarak Türkiye' deki karayolu yük hareketlerinin özelliklerini tanımlamışlar ve aynı dönem için yük taşımacılığından kaynaklı emisyon miktarını hesaplamışlardır. Çalıșmada geleneksel kamyonlar yerine Euro IV standardına sahip kamyonlar kullanılarak emisyon miktarında önemli düşüşlerin sağlanabileceği bildirilmiştir. Işık ve Kılınç (2014) ulaştırma sektöründen kaynaklı emisyonları ve ulaştırmada AR-GE harcamalarını karşılaştırmışlardır. ARGE faaliyetleri sonucu geliştirilen teknoloji ve yenilenebilir enerji kaynaklarının ulaştırmadan kaynaklı emisyonları azalttığı tespit edilmiştir. Cirit (2014) sürdürülebilir kent içi ulaşım politikalarını ve bazı büyükşehirlerdeki mevcut durumu değerlendirmiştir. Çalışmada farklı toplu taşıma sistemlerini sera gazı emisyonu açısından analiz etmiş ve emisyon miktarının en düşükten en yükseğe doğru metro, hafif raylı sistem, tramvay, metrobüs ve otobüsten kaynaklandığını belirlemiştir. Tongwane vd. (2015) 2000-2009 yılları arasında Güney Afrika ve Lesoto'da karayolu taşımacılığından kaynaklanan sera gazı emisyon miktarını Tier 2 yöntemi ile hesaplamışlardır. Emisyonların Güney Afrika'da 43,5 milyon ton, Lesoto'da 0,28 milyon ton olduğunu ve yıllık olarak Güney Afrika'da \%2,6, Lesoto'da ise \%2,5 oranında arttığını bildirmişlerdir. Ayrıca çalışma boyunca kamyonlardan kaynaklanan emisyonların hızla arttığını, diğer ulaşım türlerinden kaynaklanan emisyonların ise azaldı̆̆ını rapor etmişlerdir. 
Zhang vd. (2015) zamana bağlı toplam faktör $\mathrm{CO}_{2}$ emisyon performansındaki dinamik değişiklikleri ölçmek için Malmquist $\mathrm{CO}_{2}$ emisyon performans indeksi önermişlerdir. Çalışmada 2002-2010 yılları arası Çin ulaştırma sektöründeki ayrışmaları önerilen indeksle incelemişlerdir. Alam vd. (2017) İrlanda'da ulaştırma kaynaklı sera gazı emisyonlarının \%96’sının karayolundan kaynaklandığını bildirmişler ve 2013 yılındaki karayolu taşımacılığından kaynaklı sera gazı emisyon miktarını Tier 3 yöntemiyle araç kategorisi düzeyinde hesaplamışlardır. 2013 yılındaki emisyonların büyük bir çoğunluğunun dizel yakıtlı araçlardan kaynaklandığı, Euro II ve Euro III sınıfı binek araçların ise emisyon artışına önemli katkı sağladığı bildirilmiştir. Bıyık ve Civelekoğlu (2018) 1990-2016 yılları arasında 9 adet G20 ülkesi ile Türkiye'yi ulaştırma sektöründen kaynaklı sera gazı emisyonları açısından karşılaştırmıştır. Çalışmada Türkiye'nin herhangi bir emisyon standardının olmadığı ve karşılaştırılan ülkeler arasında \%3 emisyon azaltma hedefi ile son sırada yer aldığı belirtilmiştir. Argun vd. (2018) Selçuklu İlçesi’nin karbon ayak izini Tier 2 yöntemiyle hesaplamışlardır. Çalışmada ilçedeki toplam emisyonun \%46'sının ulaştırmadan kaynaklandığı bildirilmiştir. Eşitti ve Duran (2018) Çanakkale’ye gelen turistlerin seyahatlerinden kaynaklı karbon ayak izini Greenhouse Gaz Protokol'ündeki mesafe bazlı yöntemi kullanarak hesaplamışlardır. Toplu ulaştırmanın yetersizliğinden dolayı turistlerin özel araçlarla seyahat ettikleri ve bunun neticesinde emisyonun önemli derecede arttığını bildirmişlerdir. Yaman ve Sevimlioğlu (2018) 2010 yılı için Kocaeli’de katı atık toplamadan kaynaklı emisyon miktarını Fransız EPE kurumu tarafından geliştirilen model ile hesaplamışlardır. Kocaeli'de katı atık toplamadan kaynaklı emisyonların azaltılması amacıyla araç sefer sayılarının ve mesafelerin optimizasyonunu, aktarma istasyonlarının kurulmasını ve araçların tam dolu olarak kullanılmasını önermişlerdir. Türkay (2018) 2012-2017 yılları arasında Eskişehir'in karayolu ulaşımından kaynaklı emisyon miktarını Tier 1 yöntemi ile hesaplamıştır. Eskişehir'de zaman içerisinde karayolu kaynaklı emisyonların arttı̆̆ını bildirmiştir. Gonçalves vd. (2019) Brezilya için 2030 yılına kadar ulaştırmada enerji kullanımı ve emisyon miktarının tahmin edilmesi için senaryolar ve modeller geliştirmiş̧lerdir. Geliştirilen senaryolardan sadece bir tanesinde \%15'lik azalma gerçekleştiğini, diğer ikisinde ise \%5 ve \%15'lik bir artışın meydana geldiğini ve Brezilya’nın Paris Antlaşması kapsamında söz konusu azaltma hedeflerini arttırma potansiyeline sahip olduğunu bildirmişlerdir. Li vd. (2019) 2005-2015 yılları arasında Çin'nin 341 şehrinde ulaştırmadan kaynaklı emisyonları hesaplamışlardır. Elde edilen sonuçlara göre emisyonların karayolunda \%6,6, denizyolunda \%6,2 ve havayolunda \%9,3 arttığını, demiryolunda ise azaldığını bildirmişlerdir. Ayrıca çalışmada Çin'deki toplam emisyonun mekânsal dağılımında önemli farklılıklar olduğu ve doğu bölgelerindeki emisyon miktarının batı ve iç bölgelerine göre önemli derecede yüksek olduğu bildirilmiştir. Güzel ve Alp (2020) İstanbul'un 2016-2050 y1lları arasında karayolu taşımacılığından kaynaklı sera gazı emisyon miktarını TíMES yöntemi ile hesaplamışlardır. Çalışmada 3 farklı senaryo ele alınmış ve 2050 yılında birinci senaryoda \%1,1, ikinci senaryoda \%1,11 ve üçüncü senaryoda \%39 azaltım sağlanacağı belirtilmiştir. Emisyon limitlerinin tanımlandığı üçüncü senaryodaki azaltım, LPG ve CNG tüketiminin artması ile sağlanmıştır. Şenel ve Atabey (2020) Diyarbakır'da farklı sektörlerden kaynaklanan emisyon miktarını Tier 1 ve Tier 2 yöntemleri ile hesaplamışlardır. Çalışmada karayolu ve havayolu kaynaklı emisyonlar da hesaplanmış ve Diyarbakır'da $\mathrm{CO}_{2}$ emisyonunda ulaşım sektörünün yüksek payı olduğu bildirilmiştir. Atmaca ve Sevimlioğlu (2020) Kocaeli'de 2015-2017 yılları arasında elektrik ve 1sınma amaçlı enerji üretimi, ulaştırma ve atık yönetiminden kaynaklı sera gazı emisyonlarını Tier 1 yöntemi ile hesaplamışlardır. Şehirde yıllar itibariyle ulaştırma sektöründen kaynaklı emisyon miktarının arttığını belirlemişlerdir. Bıyık ve Civelekoğlu (2020) 2010-2016 yılları arasında Isparta'da karayolu kaynaklı sera gazı emisyonlarını Tier 1 ve Tier 2 yöntemleri ile hesaplamışlardır. Bahse konu yıllar arasında emisyonlarda Tier 1 ile \%34, Tier 2 ile yapılan hesaplamada \%43 oranında artış olduğunu bildirmişlerdir. Haksevenler vd. (2020) Ümraniye İlçesi'nin emisyon miktarını Tier 1 ve Tier 2 yöntemleri ile hesaplamışlardır. Çalışmada konutlar, ticarethane ve resmi kurumlardan sonra ulaştırma sektörünün üçüncü sırada yer aldığı, toplam emisyonun \%16'sını ürettiği ve ulaştırmadan kaynaklı emisyonların \%50'sinin bireysel araç kullanımından, \%12'sinin ise toplu ulaştırmadan kaynaklandığı bildirilmiştir. Öncü ve Özdemir (2020) 2007-2017 yılları arasında 33 ülkeyi ekonomik büyüme ve ulaştırma altyapı kalitesinin neden olduğu çevresel etkiler açısından karşılaştırmışlardır. Çalışmada ekonomik büyüme ve lojistik sektöründeki genişlemeye paralel olarak sera gazı emisyonunun arttığı ve ülkelerdeki ulaştırma altyapı kalitesinin emisyon üzerinde etkili olduğu belirlenmiştir. Cansız ve Ünsalan (2020) Hatay’ın İskenderun İlçesi'nde üretilen filtrelerin diğer illere tek türde ve karma taşımacılıktan kaynaklanan sera gazı emisyon miktarını karşılaştırmışlardır. Karma taşımacılık mümkün olan iller için karayolu, demiryolu, denizyolu ve feribot seçeneklerinin farklı kombinasyonları değerlendirilmiştir. Elde edilen sonuçlara göre karma taşımacılığın tek türde taşımacılığa göre emisyon açısından çok daha avantajlı olduğunu bildirmişlerdir. Dündar ve Kolay (2021) 2010-2018 yılları arasında Konya'da karayolu yük ve yolcu taşımacılığından kaynaklı sera gazı emisyon miktarlarını Tier 1 yöntemi ile hesaplamışlardır. Söz konusu yıllar arasında emisyon miktarının toplamda \%87, kişi başına düşen emisyon oranının ise $\% 70$ oranında arttı̆̆ını bildirmişlerdir.

Yukarıda özetlenen çalışmalar incelendiğinde uluslararası alanda birden çok şehrin karşılaştırmalı analizlerinin yapıldığı çalışmalar olduğu görülmektedir. Türkiye'de genellikle yıllar itibariyle şehir bazında sera gazı emisyonlarının hesaplandığ 1 çalışmalar bulunmakla birlikte, şehirlerin beraber incelendiği ve karşılaştırıldığı bir çalışmaya rastlanılmamıştır. Literatürdeki bu boşluğu doldurmak amacıyla çalışmada ülkemizde 2019 yılı itibariyle büyükşehir statüsüne sahip şehirlerin karayolu ulaşımından kaynaklı sera gazı emisyonları Tier 1 yöntemi ile hesaplanacak ve bazı kriterlere göre bu sonuçlar karşılaştırılarak analiz edilecektir. 


\section{Materyal ve Metot}

Hükümetler Arası İklim Değişikliği Paneli (IPCC) iklim değişikliği ile ilgili bilimsel çalışmalar yapmak amacıyla kurulan uluslararası bir kuruluştur. IPCC bünyesindeki farklı ülkelerden konuyla ilgili bilim insanlarının yaptığı çalışmaları raporlar şeklinde yayınlanmaktadır. IPCC, standartları sağlamak ve hesaplamaların kolaylaştırılması amacıyla sera gazı emisyonlarının hesaplanması için Tier yöntemini geliştirmiştir. Tier yönteminde 3 farklı seviye bulunmakla birlikte, bu seviyeler hesaplamada kullanılan teknolojik detaylara göre değişmektedir. Tier 1 yakıt tüketimini yani ulusal enerji istatistiklerini esas alarak az veri ile hesaplama yapılabilecek bir yöntemdir. Tier 2 orta (yakıtın yanma teknolojisi) ve Tier 3 ise yüksek (yanma teknolojisine ait detaylı veri) karmaşıklık seviyesinde veriye ihtiyaç duyan yöntemlerdir. Bu yöntemlerde kullanılan veriler sağlanabilirse gerçeğe daha yakın hesaplamalar yapılabilmektedir (IPCC 2006). Bu çalışmada daha az veri ile hesaplama sağladı̆̆ı için Tier 1 yöntemi kullanılmıştır.

IPCC, Tier yaklaşımlarında hesaplama yönteminde kullanılacak veriler olması durumunda anahtar sektörün belirlenmesini istemekte ve bu anahtar sektörlerde hesaplanacak gazları vermektedir. Çalışma kapsamında IPCC tarafından belirlenen karayolu taşımacılığından kaynaklı yakıt yakımının ele alındığı 1A3b kategorisi anahtar sektör olarak belirlenmiştir. Bu kategoride her bir yakıt türü (benzin, motorin, LPG) için $\mathrm{CO}_{2}, \mathrm{CH}_{4}, \mathrm{~N}_{2} \mathrm{O}$ gazlarından kaynaklı emisyonlar hesaplanmalı ve bu değerler toplanmalıdır. Bu değerler yakıt türünün emisyon miktarını vermektedir. Tüm yakıt türlerine ait emisyon verileri toplanarak toplam emisyon miktarına ulaşılmaktadır (IPCC 2006a). Aşağıda Tier 1 hesaplama yöntemi verilmektedir.

Her bir yakıt türüne ait tüketim miktarları, ilgili dönüşüm faktörü ile çarpılarak enerji tüketim miktarları elde edilir.

Enerji Tüketimi $[\mathrm{TJ}]=$ Yakıt Tüketimi $[\mathrm{t}] \times 10^{-3} \times$ Dönüşüm Faktörü $\left[\frac{\mathrm{TJ}}{\mathrm{kt}}\right]$

Enerji tüketim miktarları ilgili karbon emisyon faktörü ile çarpılarak yakıt yakımından kaynaklanan karbon içeriği hesaplanir.

$$
\text { Karbon İçeriği }[\mathrm{Gg} \mathrm{C}]=\text { Karbon Emisyon Faktörü }\left[\mathrm{t} \frac{\mathrm{C}}{\mathrm{TJ}}\right] \times \text { Enerji Tüketimi }[\mathrm{TJ}] \times 10^{-3}
$$

Karbon içeriği $\mathrm{CO}_{2}$ için ilgili oksitlenme oranı, $\mathrm{CH}_{4}$ ve $\mathrm{N}_{2} \mathrm{O}$ için küresel 1sınma katsayısı ile çarpılarak karbon emisyon miktarı hesaplanır.

$$
\text { Karbon Emisyonu [Gg C] = Karbon İçeriği [Gg C] × Oksitlenme Oranı (Küresel Isınma Kat Sayısı) }
$$

Hesaplanan karbon emisyon miktarı karbondioksit ile karbonun molekül ağırlığı oranı çarpılarak sera gazı emisyon miktarı $\mathrm{CO}_{2}$ e. cinsinden hesaplanmaktadır.

$$
\text { Sera Gazı Emisyonu [Gg } \left.\mathrm{CO}_{2} \mathrm{e} .\right]=\text { Karbon Emisyonu [Gg C] } \times \text { Molekül Ağırlığı Oranı }
$$

Yukarıda anlatılan hesaplamada her bir yakıt türü (benzin, motorin, LPG) için her bir gazdan $\left(\mathrm{CO}_{2}, \mathrm{CH}_{4}, \mathrm{~N}_{2} \mathrm{O}\right)$ kaynaklanan emisyonlar ayrı ayrı hesaplanmaktadır. Çıkan sonuçlar toplanarak toplam sera gazı emisyon miktarına ulaşılmaktadır.

IPCC kılavuzunda yayınlanan ve Tier 1 hesaplama yönteminde kullanılan ilgili yakıtlara ait dönüşüm faktörü, karbon emisyon faktörü, oksitlenme oranı, küresel ısınma kat sayısı ve karbondioksit ile karbonun molekül ağırlığı oranı Tablo 1 'de verilmiştir.

Tablo 1: Tier 1 Yönteminde kullanılan değerler (IPCC 2006b; IPCC 2006c; IPCC 2015)

\begin{tabular}{lcccccccc}
\hline YAKIT & $\begin{array}{c}\text { Dönüşüm } \\
\text { Faktörü }\end{array}$ & \multicolumn{2}{c}{$\begin{array}{c}\text { Karbon Emisyon Faktörü } \\
\text { (kg/TJ) }\end{array}$} & $\begin{array}{c}\text { Oksitlenme } \\
\text { Oranı }\end{array}$ & \multicolumn{2}{c}{$\begin{array}{c}\text { Küresel Isınma } \\
\text { Kat Sayısı }\end{array}$} & $\begin{array}{c}\text { Molekül } \\
\text { Ağırlı̆̆ Oranı }\end{array}$ \\
\cline { 2 - 8 } Benzin & & $\mathbf{C O}_{\mathbf{2}}$ & $\mathbf{C H}_{\mathbf{4}}$ & $\mathbf{N}_{\mathbf{2}} \mathbf{O}$ & $\mathbf{C O}_{\mathbf{2}}$ & $\mathbf{C H}_{\mathbf{4}}$ & $\mathbf{N}_{\mathbf{2}} \mathbf{O}$ & \\
Motorin & 44,3 & 18,9 & 33 & 3,2 & 0,99 & 28 & 265 & $44 / 12$ \\
LPG & 43,0 & 20,2 & 3,9 & 3,9 & 0,99 & 28 & 265 & $44 / 12$ \\
\hline
\end{tabular}

Çalışmada, Türkiye’de büyükşehir statüsüne sahip 30 şehrin 2010 ve 2019 yılları yakıt satış miktarları, Enerji Piyasası Düzenleme Kurumu (EPDK) raporlarında yer alan satış verileri esas alınarak hesaplanmış ve Tablo 2'de gösterilmiştir. 
Tablo 2: 2010 ve 2019 yıllarında gerçekleşen yakıt satış verileri (EPDK2011a; EPDK2011b; EPDK2020a; EPDK2020b)

\begin{tabular}{|c|c|c|c|c|c|c|}
\hline \multirow[b]{3}{*}{ Adana } & \multicolumn{3}{|c|}{2010} & \multicolumn{3}{|c|}{2019} \\
\hline & BENZİN & MOTORIN & LPG & BENZİN & MOTORIN & LPG \\
\hline & 43.662 & 317.459 & 64.638 & 53.450 & 474.792 & 102.540 \\
\hline Ankara & 165.234 & 1.014 .935 & 314.091 & 209.747 & 1.980 .007 & 373.859 \\
\hline Antalya & 89.223 & 462.422 & 96.067 & 102.198 & 724.289 & 113.776 \\
\hline Aydin & 33.090 & 179.981 & 39.170 & 43.045 & 320.479 & 57.267 \\
\hline Balıkesir & 40.096 & 257.328 & 41.593 & 52.551 & 424.465 & 61.633 \\
\hline Bursa & 85.383 & 486.490 & 67.790 & 111.755 & 848.730 & 100.932 \\
\hline Denizli & 24.465 & 215.009 & 39.472 & 31.028 & 528.109 & 65.559 \\
\hline Diyarbakır & 13.923 & 121.005 & 29.199 & 18.760 & 192.735 & 40.112 \\
\hline Erzurum & 9.893 & 95.649 & 16.942 & 14.524 & 136.275 & 22.299 \\
\hline Eskişehir & 23.953 & 199.658 & 29.516 & 28.804 & 309.893 & 38.868 \\
\hline Gaziantep & 26.029 & 279.050 & 46.224 & 43.390 & 546.700 & 74.676 \\
\hline Hatay & 26.673 & 200.989 & 36.039 & 38.281 & 436.038 & 62.284 \\
\hline İstanbul & 534.495 & 2.211 .314 & 283.981 & 554.999 & 3.613 .545 & 271.656 \\
\hline İzmir & 125.914 & 747.277 & 161.193 & 148.594 & 1.195 .789 & 160.283 \\
\hline Kahramanmaraş & 11.770 & 130.123 & 41.446 & 19.803 & 198.915 & 71.656 \\
\hline Kayseri & 22.950 & 223.253 & 58.541 & 35.730 & 335.336 & 85.169 \\
\hline Kocaeli & 54.105 & 367.041 & 46.255 & 67.539 & 761.700 & 75.638 \\
\hline Konya & 36.867 & 416.274 & 96.687 & 50.911 & 732.986 & 136.565 \\
\hline Malatya & 9.830 & 115.130 & 22.224 & 15.490 & 136.034 & 33.717 \\
\hline Manisa & 30.141 & 215.381 & 53.703 & 44.033 & 521.812 & 85.768 \\
\hline Mardin & 4.005 & 31.537 & 11.359 & 7.223 & 143.897 & 15.902 \\
\hline Mersin & 42.119 & 531.445 & 56.211 & 50.487 & 822.306 & 87.016 \\
\hline Muğla & 49.772 & 221.519 & 40.658 & 66.753 & 369.512 & 59.880 \\
\hline Ordu & 10.471 & 82.717 & 20.466 & 15.651 & 133.332 & 26.842 \\
\hline Sakarya & 22.726 & 196.171 & 48.172 & 30.566 & 271.129 & 71.987 \\
\hline Samsun & 21.872 & 246.314 & 43.007 & 29.994 & 402.209 & 61.071 \\
\hline Şanlıurfa & 11.643 & 94.156 & 50.553 & 21.372 & 271.130 & 81.776 \\
\hline Tekirdağ & 31.821 & 234.261 & 17.164 & 40.674 & 338.822 & 27.582 \\
\hline Trabzon & 13.930 & 146.113 & 19.268 & 18.763 & 231.091 & 20.811 \\
\hline Van & 7.131 & 27.338 & 9.800 & 10.460 & 76.779 & 17.845 \\
\hline Toplam & 1.623.186 & 10.067.339 & 1.901.429 & 1.976.576 & 17.478.837 & 2.504 .969 \\
\hline
\end{tabular}

2010 ve 2019 yıllarında 30 büyükşehirde benzin satış miktarları sırasıyla Şekil 2 ve Şekil 3'de verilmiştir.

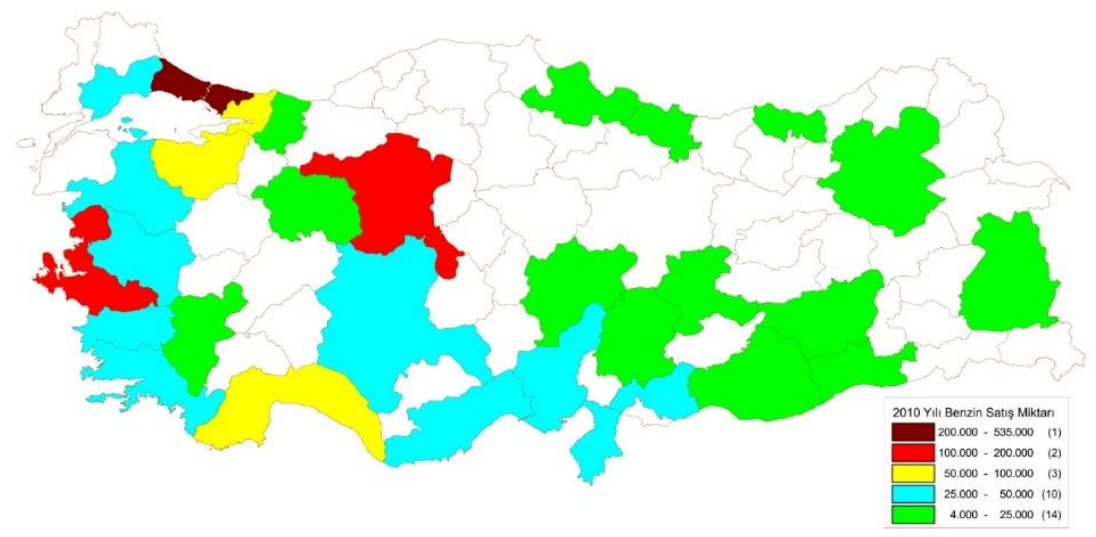

Şekil 2: 2010 yılında büyükşehirlerdeki benzin satış miktarları (ton) (EPDK 2011a) 


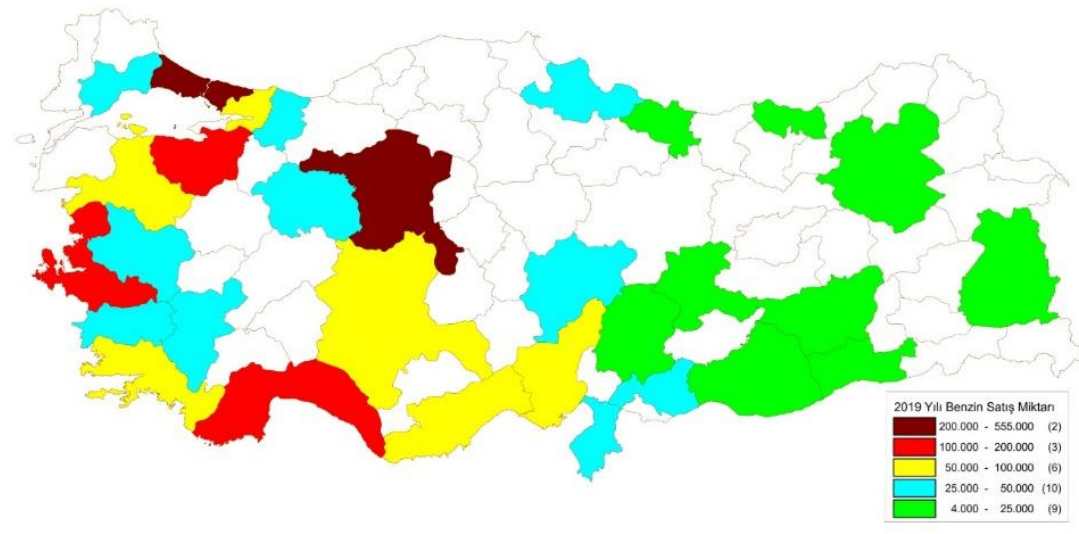

Şekil 3: 2019 yılında büyükşehirlerdeki benzin satış miktarları (ton) (EPDK 2020a)

Ülkemizde 2000'li yıllardan sonra araçlarda LPG kullanımının hızla artması sonucu benzin tüketimi buna paralel olarak azalmıştır. Bu sebeple büyükşehirlerde de en az tüketilen yakıt türü benzindir. 2010 yılında en çok benzin tüketimi sırasıyla İstanbul, Ankara ve İzmir'dedir. Bu şehirlerdeki tüketim 100 bin tonun üstündedir. En az benzin tüketimi ise Mardin, Van, Malatya ve Erzurum şehirlerinde olup 10 bin tondan azdır. 2019 yılına gelindiğinde ise İstanbul, Ankara ve İzmir'e ilaveten Bursa ve Antalya'da da benzin tüketimi 100 bin tonu geçmiştir. Sadece Mardin'de tüketim 10 bin tonun altında olup Van, Malatya ve Erzurum'daki benzin tüketimi 10 bin tonu geçmiştir. 2010-2019 yılları arasında büyükşehirlerde benzin tüketimi oransal olarak en fazla \%80,34 ile Mardin'de, en az \%3,83 ile İstanbul'dadır. Büyükşehirlerde benzin tüketimindeki toplam artı̧ \%21,77 olarak gerçekleşmiştir.

2010 ve 2019 yıllarında 30 büyükşehirde motorin satış miktarları sırasıyla Şekil 4 ve Şekil 5’te verilmiştir.

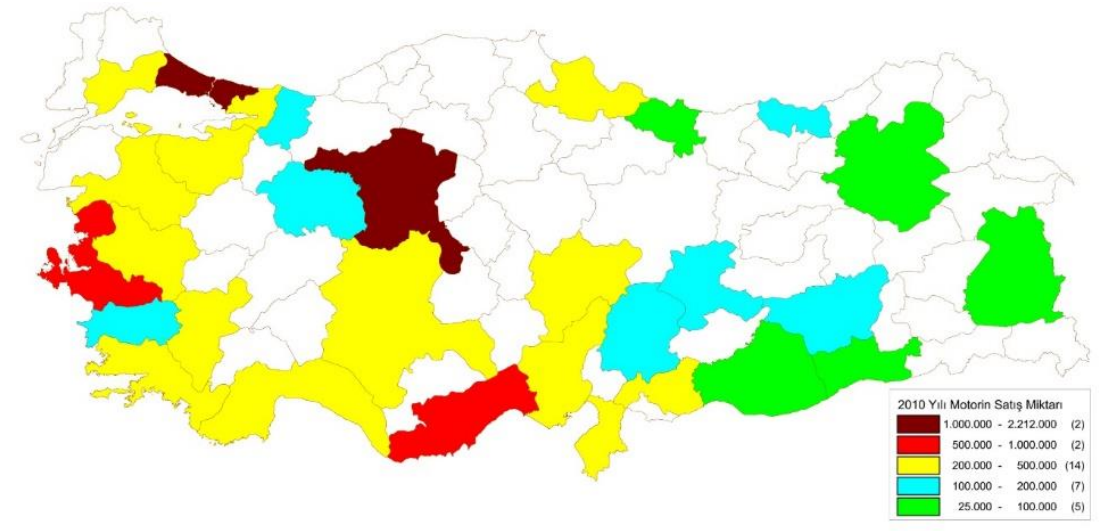

Şekil 4: 2010 yılında büyükşehirlerdeki motorin satış miktarları (ton) (EPDK 2011a)

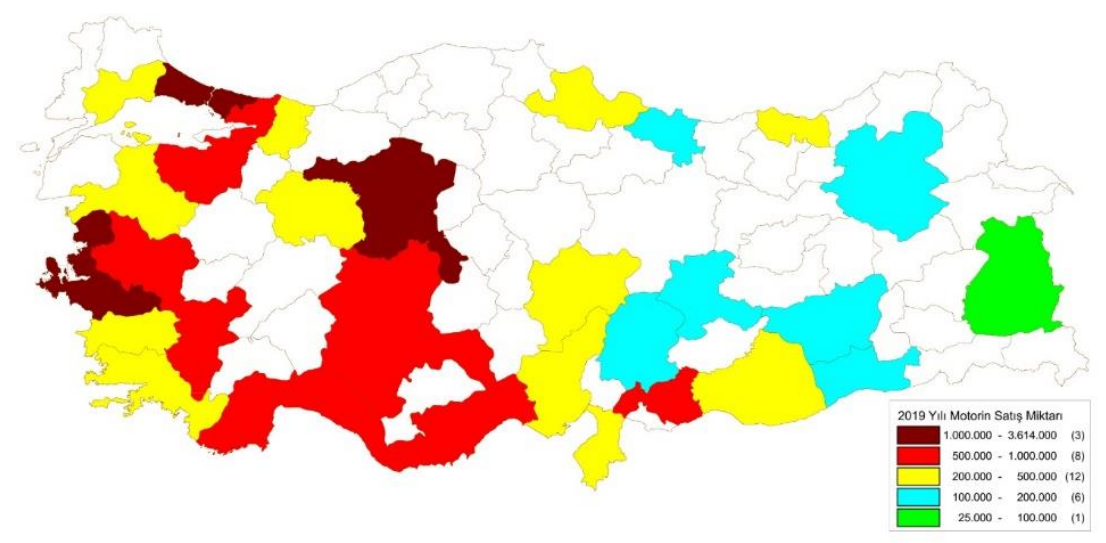

Şekil 5: 2019 yılında büyükşehirlerdeki motorin satış miktarları (ton) (EPDK 2020a) 
Ülkemizde nispeten ucuz ve $\mathrm{km}$. başına tüketimin az olması sebebiyle karayolu ulaşımında en fazla motorin tüketilmektedir. Buna paralel olarak 2010 ve 2019 yıllarında büyükşehirlerde de yakıtlar arasında en fazla motorin tüketimi gerçekleşmiştir. 2010 yılında en çok motorin satışı sırasıyla İstanbul ve Ankara'da bir milyon tonun üstündedir. En az motorin satışı ise sırasıyla Van, Mardin, Ordu, Şanlıurfa ve Erzurum'dadır. Bu şehirlerdeki motorin tüketimi 100 bin tonun altındadır. 2019 yılında ise en çok tüketimin olduğu şehirlerde sıralama değişmemiş ve İzmir'de bir milyon tonun üstünde tüketim gerçekleşen şehirler arasına girmiştir. En az motorin tüketimi Van'dadır. 2019 yılında 100 bin tonun altında motorin tüketimi sadece Van'da gerçekleşmiştir. 2010'dan 2019 yılına en fazla değişim \%322 ile Mardin'de, en az ise \%44,73 ile Şanlıurfa'dadır. Büyükşehirlerdeki toplam motorin tüketiminin 2010'dan 2019'a \%73,61 oranında arttı̆̆ 1 tespit edilmiştir.

2010 ve 2019 yıllarında 30 büyükşsehirde LPG satış miktarları sırasıyla Şekil 6 ve Şekil 7'de verilmiştir.

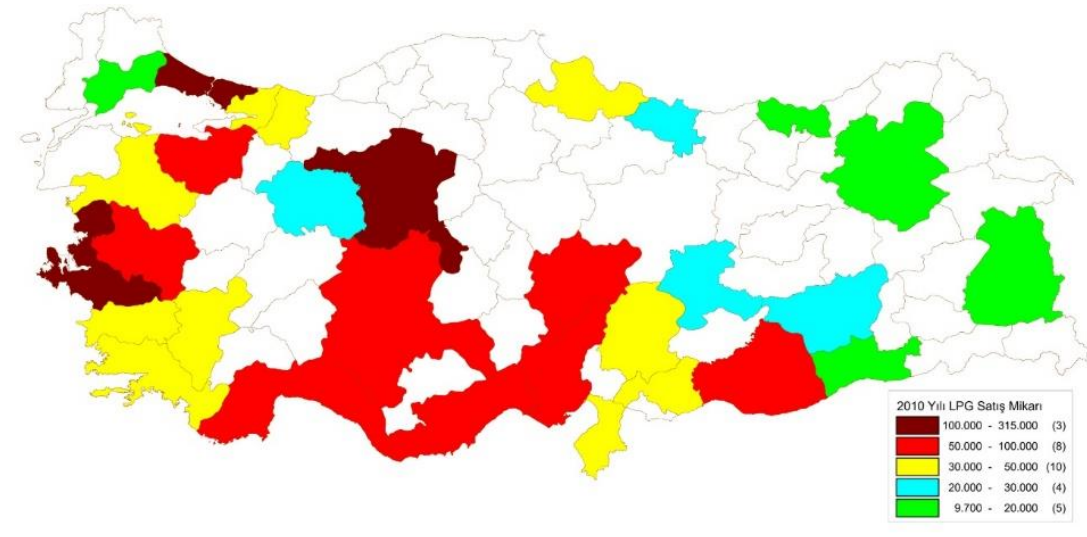

Şekil 6: 2010 yılında büyükşehirlerdeki LPG satış miktarları (EPDK 2011b)

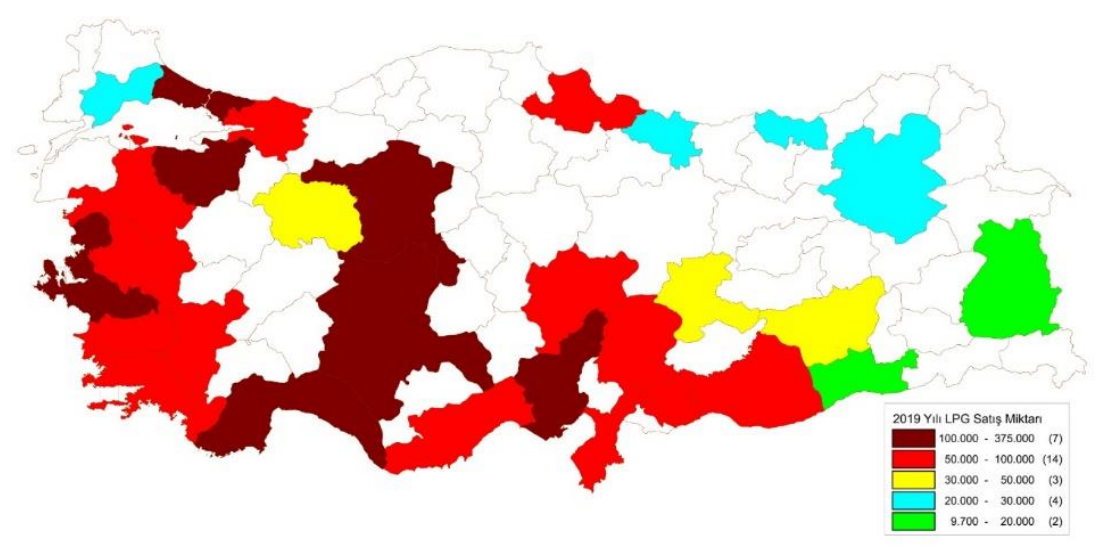

Şekil 7: 2019 yılında büyükşehirlerdeki LPG satış miktarları (EPDK 2020b)

Ülkemizde yakıt tüketiminde motorinden sonra ikinci sırada LPG yer almaktadır. 2010 yılında en çok tüketim sırasıyla Ankara, İstanbul ve İzmir'de 100 bin tonun üstündedir. Ankara LPG tüketiminde İstanbul'u geçerek birinci sıraya yükselmiştir. 2010 yılında en az tüketim ise sırasıyla Van, Mardin, Erzurum, Tekirdağ ve Trabzon'da 20 bin tonun altındadır. 2019 yılına gelindiğinde ise 100 bin tonun üzerinde tüketim gerçekleşen şehir sayısı yediye çıkmıştır. Bunlar sırasıyla Ankara, İstanbul, İzmir, Konya, Antalya, Adana ve Bursa'dır. Mardin ve Van'da tüketim 20 bin tonun altındadır. Erzurum, Tekirdağ ve Trabzon'un LPG tüketimi 20 bin tonun üstüne çıkmıştır. 2010-2019 yılları arasında değişime bakıldığında ise LPG tüketiminde en fazla artış \%66,61 ile Samsun'da, \%62,26 ile Van'da ve \%61,76 ile Şanlıurfa'dadır. 2010-2019 yılları arasındaki LPG tüketimi İstanbul'da \% 4,34 ve İzmir'de ise \%0,56 oranında azalmıştır. Büyükşehirlerde toplam LPG tüketimi 2010-2019 yılları arasında \%31,74 oranında artmıştır.

Çalışmada kişi başına, araç başına ve $\mathrm{km}^{2}$ 'ye düşen sera gazı emisyon miktarlarını hesaplamak için kullanılacak 30 büyükşsehre ait 2010 ve 2019 yılları nüfus sayıları, toplam karayolu araç sayıları (otomobil, minibüs, otobüs, kamyonet, kamyon ve traktör) ve şehirlerin yüzölçümleri Tablo 3'de verilmiştir. 
Tablo 3: 2010 ve 2019 yıllarında büyükşehirlerin nüfus, toplam araç sayıları ve yüzölçümleri (TUiK 2020a; TUIK 2020b; HGM 2020)

\begin{tabular}{|c|c|c|c|c|c|}
\hline & \multicolumn{2}{|c|}{2010} & \multicolumn{2}{|c|}{2019} & \multirow[b]{2}{*}{ Yüz Ölçümleri $\left(\mathbf{k m}^{2}\right)$} \\
\hline & Nüfus Sayıları & Toplam Araç Sayısı & Nüfus Sayıları & Toplam Araç Sayısı & \\
\hline Adana & 2.085 .225 & 335.327 & 2.237 .940 & 522.234 & 13.844 \\
\hline Ankara & 4.771 .716 & 1.249 .300 & 5.639 .076 & 1.973 .950 & 25.632 \\
\hline Antalya & 1.978 .333 & 481.341 & 2.511 .700 & 808.822 & 20.177 \\
\hline Aydın & 989.862 & 202.479 & 1.110 .972 & 322.797 & 8.116 \\
\hline Balıkesir & 1.152 .323 & 238.369 & 1.228 .620 & 364.493 & 14.583 \\
\hline Bursa & 2.605 .495 & 473.647 & 3.056 .120 & 796.837 & 10.813 \\
\hline Denizli & 931.823 & 213.401 & 1.037 .208 & 337.536 & 12.134 \\
\hline Diyarbakır & 1.528 .958 & 87.982 & 1.756 .353 & 110.649 & 15.168 \\
\hline Erzurum & 769.085 & 77.625 & 762.062 & 115.458 & 25.006 \\
\hline Eskişehir & 764.584 & 162.281 & 887.475 & 254.578 & 13.960 \\
\hline Gaziantep & 1.700 .763 & 223.016 & 2.069 .364 & 397.464 & 6.803 \\
\hline Hatay & 1.480 .571 & 196.021 & 1.628 .894 & 336.369 & 5.524 \\
\hline İstanbul & 13.255 .685 & 2.612 .739 & 15.519 .267 & 3.845 .987 & 5.461 \\
\hline İzmir & 3.948 .848 & 796.856 & 4.367 .251 & 1.156 .324 & 11.891 \\
\hline Kahramanmaraş & 1.044 .816 & 119.864 & 1.154 .102 & 213.984 & 14.520 \\
\hline Kayseri & 1.234 .651 & 231.129 & 1.407 .409 & 359.636 & 16.970 \\
\hline Kocaeli & 1.560 .138 & 220.945 & 1.953 .035 & 367.883 & 3.397 \\
\hline Konya & 2.013 .845 & 394.885 & 2.232 .374 & 616.568 & 40.838 \\
\hline Malatya & 740.643 & 96.886 & 800.165 & 165.647 & 12.259 \\
\hline Manisa & 1.379 .484 & 263.866 & 1.440 .611 & 407.381 & 13.339 \\
\hline Mardin & 744.606 & 46.306 & 838.778 & 67.768 & 8.780 \\
\hline Mersin & 1.647 .899 & 279.226 & 1.840 .425 & 468.376 & 16.010 \\
\hline Muğla & 817.503 & 210.142 & 983.142 & 341.180 & 12.654 \\
\hline Ordu & 719.183 & 77.507 & 754.198 & 129.272 & 5.861 \\
\hline Sakarya & 872.872 & 153.621 & 1.029 .650 & 254.547 & 4.824 \\
\hline Samsun & 1.252 .693 & 204.170 & 1.348 .542 & 321.119 & 9.725 \\
\hline Şanlıurfa & 1.663 .371 & 140.745 & 2.073 .614 & 184.590 & 19.242 \\
\hline Tekirdağ & 798.109 & 135.470 & 1.055 .412 & 238.800 & 6.190 \\
\hline Trabzon & 763.714 & 104.487 & 808.974 & 189.851 & 4.628 \\
\hline Van & 1.035 .418 & 60.962 & 1.136 .757 & 73.382 & 20.921 \\
\hline TOPLAM & 56.252 .216 & 10.090 .595 & 64.669 .490 & 15.743 .482 & 399.270 \\
\hline
\end{tabular}

Tablo 3'deki nüfus sayıları incelendiğinde Erzurum'da \%0,91 oranında azalış, diğer bütün şehirlerde ise artış olduğu görülmektedir. 2010 ve 2019 yıllarında nüfusun en yoğun olduğu ilk üç şehir sırasıyla İstanbul, Ankara ve İzmir' dir. 2010 yılında yedinci sırada yer alan Antalya, 2019 yılında 533,367 kişi artarak beşinci sıraya yükselmiştir. Şanlıurfa, Kocaeli ve Kayseri şehirleri de 2019 yılında sıralamada birer basamak yükselmişlerdir. 2010 yılında nüfusun en az olduğu şehirler sırasıyla Ordu, Malatya, Mardin iken 2019 y1lında bu sıra Ordu, Erzurum, Malatya şeklinde gerçekleşmiş̧ir. 2010-2019 yılları arasında nüfusu en çok artan şehirler sırasıyla $\% 32,23$ ile Tekirdağ, $\% 26,96$ ile Antalya ve $\% 25,18$ ile Kocaeli'dir. Erzurum'daki azalmanın yanı sıra nüfusu en az artan şehirler sırasıyla \%4,43 ile Manisa, \%4,86 ile Ordu, \%5,92 ile Trabzon'dur. Araç sayıları değerlendirildiğinde 2010 yılında yaklaşık İstanbul'da 2,6 milyon, Ankara'da ise 1,25 milyon araç bulunduğu görülmektedir. En az araç ise sırasıyla Mardin, Van, Ordu, Erzurum, Diyarbakır ve Malatya'da olmakla birlikte bu şehirlerde araç sayıları 100 binin altındadır. 2019 yılında İzmir'de de araç sayısı bir milyonun üstüne, Antalya, Bursa, Konya ve Adana'da 500 binin üstüne çıkmıştır. En az araç bulunan şehirler ise sırasıyla Mardin ve Van olmuştur. $\mathrm{Bu}$ şehirlerdeki araç sayıları 100 binin altındadır. Diğer taraftan 2010-2019 yılları arasında 30 büyükşehirde otomobil $\% 65,40$, kamyonet $\% 53,82$, traktör $\% 35,71$, minibüs $\% 31,96$, kamyon $\% 18,13$ ve otobüs $\% 0,82$ oranında artmıştır.

Birçok çalışmada karayolu taşımacılı̆̆ından kaynaklı sera gazı emisyonlarının azaltılması için alternatif taşıma modları, toplu ulaşımın yaygınlaştırılması ve lojistik merkez gibi alt yapılar önerilmektedir. Ülkemizde karayoluna alternatif olarak demiryolu taşımacılığı yoğun olarak kullanılmaktadır. Şehir içi toplu ulaşımda metro, hafif raylı sistem (HRS), banliyö ve tramvay kullanılmakta iken, şehirler arası yolcu taşımacıllğında yüksek hızlı tren(YHT) ve konvansiyonel demiryolu taşımacılığı aktif olarak kullanılmaktadır. Yük taşımacılığında ise konvansiyonel demiryolu taşımacılığına ilaveten, yüklerin konsolide edildiği, yüklerin modlar arası aktarıldığı ve şehir içi lojistik açısından son derece önemli lojistik merkezler hızla yaygınlaşmaktadır. Lojistik merkez şehir içindeki yoğun ve plansız lojistik hareketleri önleyerek trafik sıkışıklığını azaltmada ve çevre kirliliğini önlemede önemli rol üstlenmektedir (Elgün ve Aşıkoğlu 2016; Baki, 2018). Murphy ve Poist (2003) yaptıkları çalışmada lojistik merkezlerin şehir trafiğinde araç kilometre sayısında \%60 azaltma sağladığını bildirmiștir. Belgrad ve Novi Sad'da lojistik merkez kullanımının artmasına paralel olarak araç kullanımı \%30-60 oranında azalmış ve emisyon miktarında düşüşler görülmüştür (Pamučar vd. 2016). Yukarıda bahsi geçen emisyon azaltıcı etkisi bulunan alternatif taşıma seçenekleri ve lojistik merkezlerin 2019 yılı itibariyle hangi büyükşehirlerde faaliyette olduğu aşağıdaki Tablo 4'te verilmiştir. Tablo 4'deki veriler TCDD raporları esas alınarak hazırlanmıştır. Ancak bu raporlarda yer almayan Ankara Lojistik Üssü’de verilere sonradan eklenmiştir. 
Tablo 4: Büyükşehirlerde kullanılan alternatif taşıma yöntemleri ve alt yapı varlığı (TCDD 2020a; TCDD 2020b)

\begin{tabular}{|c|c|c|c|c|c|}
\hline & Metro / HRS & Banliyö / Tramvay & YHT & Lojistik Merkez & Demiryolu Bağlantısı \\
\hline Adana & Aktif & & & & Aktif \\
\hline Ankara & Aktif & Aktif & Aktif & Aktif & Aktif \\
\hline Antalya & & Aktif & & & \\
\hline Aydin & & & & & Aktif \\
\hline Balıkesir & & & & Aktif & Aktif \\
\hline Bursa & & Aktif & & & \\
\hline Denizli & & & & Aktif & Aktif \\
\hline Diyarbakır & & & & & Aktif \\
\hline Erzurum & & & & Aktif & Aktif \\
\hline Eskişehir & & Aktif & Aktif & Aktif & Aktif \\
\hline Gaziantep & & Aktif & & & Aktif \\
\hline Hatay & & & & & Aktif \\
\hline İstanbul & Aktif & Aktif & Aktif & Aktif & Aktif \\
\hline İzmir & Aktif & Aktif & & & Aktif \\
\hline Kahramanmaraş & & & & Aktif & Aktif \\
\hline Kayseri & & Aktif & & & Aktif \\
\hline Kocaeli & & Aktif & Aktif & Aktif & Aktif \\
\hline Konya & & Aktif & Aktif & & Aktif \\
\hline Malatya & & & & & Aktif \\
\hline Manisa & & & & & Aktif \\
\hline Mardin & & & & & Aktif \\
\hline Mersin & & & & Aktif & Aktif \\
\hline \multicolumn{6}{|l|}{ Muğla } \\
\hline \multicolumn{6}{|l|}{ Ordu } \\
\hline Sakarya & & & Aktif & & Aktif \\
\hline Samsun & Aktif & & & Aktif & Aktif \\
\hline Şanlıurfa & & & & & Aktif \\
\hline Tekirdă̆ & & & & & Aktif \\
\hline \multicolumn{6}{|l|}{ Trabzon } \\
\hline Van & & & & & Aktif \\
\hline
\end{tabular}

Diğer taraftan planlanan, yapımı devam eden banliyö, HRS, lojistik merkezler ve YHT projeleri bulunmakla birlikte, Tablo 4'te sadece 2019 yılı itibariyle aktif olarak kullanılanlara yer verilmiştir.

\section{Bulgular}

Metot bölümünde ayrıntılı bilgisi verilen Tier 1 yöntemi ile yapılan hesaplamalar sonucunda elde edilen büyükşehirlere ait sera gazı emisyon miktarları Tablo 5'te verilmiştir. Tablo 5 incelendiğinde 2010 yılında en çok sera gazı emisyonu sırasıyla İstanbul, Ankara ve İzmir'de gerçekleşmiştir. Bu şehirlerdeki emisyon miktarı 3.000 Gg $\mathrm{CO}_{2} \mathrm{e}$.' in üstündedir. En az emisyon miktarı ise sırasıyla Van, Mardin, Ordu ve Erzurum'dadır. Bu şehirlerdeki karbon emisyon miktarı $400 \mathrm{Gg}$ $\mathrm{CO}_{2}$ e.'in altındadır. 2019 yılında ise yine en çok emisyon sırasıyla ilk üç büyük şehir olan İstanbul, Ankara ve İzmir'dedir. 2019 yılında bu şehirlerdeki emisyon miktarı $4.800 \mathrm{Gg} \mathrm{CO}_{2}$ e.'in üstündedir. En az emisyonun gerçekleştiği şehirler ise sırasıyla Van, Mardin, Erzurum, Ordu ve Malatya'dır. Ordu şehrindeki emisyon miktarı 2019 yılında Erzurum'u geçmiştir. Bu şehirlerdeki emisyon miktarı Van'da $400 \mathrm{Gg} \mathrm{CO}_{2}$ e.'in, diğer şehirlerde ise $600 \mathrm{Gg} \mathrm{CO}_{2}$ e.'in altındadır. 30 Büyükşehirde 2010 yılında toplam sera gazı emisyon miktarı $43.403 \mathrm{Gg} \mathrm{CO}_{2} \mathrm{e}$. iken, 2019 yılında $70.271 \mathrm{Gg} \mathrm{CO}_{2} \mathrm{e}$. olarak gerçekleşmiştir. Büyükşsehirlerde ortalama emisyon miktarı ise 2010 yılında 1446,77 $\mathrm{Gg} \mathrm{CO}_{2} \mathrm{e}$. iken, 2019 yılında 2342,40 $\mathrm{Gg} \mathrm{CO}_{2}$ e.'e yükselmiştir. 
Tablo 5 : 2010 ve 2019 yıllarında büyükşehirlerin sera gazı emisyon miktarları (Gg CO $2 e$.

\begin{tabular}{|c|c|c|c|c|c|c|c|c|}
\hline & \multicolumn{4}{|c|}{2010} & \multicolumn{4}{|c|}{2019} \\
\hline & $\mathrm{CO}_{2}$ & $\mathrm{CH}_{4}$ & $\mathrm{~N}_{2} \mathrm{O}$ & Toplam & $\mathrm{CO}_{2}$ & $\mathrm{CH}_{4}$ & $\mathrm{~N}_{2} \mathrm{O}$ & Toplam \\
\hline Adana & $1.334,73$ & 8,59 & 15,91 & $1.359,23$ & $1.977,22$ & 12,84 & 23,36 & $2.013,42$ \\
\hline Ankara & $4.664,99$ & 37,32 & 52,10 & $4.754,41$ & $8.045,49$ & 48,58 & 96,81 & $8.190,88$ \\
\hline Antalya & $2.028,65$ & 13,71 & 24,14 & $2.066,50$ & $2.953,11$ & 16,93 & 36,31 & $3.006,35$ \\
\hline Aydın & 789,83 & 5,42 & 9,34 & 804,59 & $1.320,55$ & 7,97 & 16,00 & $1.344,52$ \\
\hline Balıkesir & $1.064,31$ & 6,26 & 13,05 & $1.083,62$ & $1.693,11$ & 9,21 & 20,99 & $1.723,31$ \\
\hline Bursa & $2.009,37$ & 11,35 & 25,00 & $2.045,71$ & $3.339,73$ & 16,85 & 42,17 & $3.398,75$ \\
\hline Denizli & 875,51 & 5,25 & 10,57 & 891,33 & $1.967,92$ & 9,13 & 24,80 & $2.001,85$ \\
\hline Diyarbakır & 513,94 & 3,54 & 5,97 & 523,45 & 789,11 & 4,97 & 9,37 & 803,44 \\
\hline Erzurum & 384,60 & 2,25 & 4,66 & 391,51 & 543,82 & 3,07 & 6,66 & 553,54 \\
\hline Eskişehir & 795,60 & 4,34 & 9,85 & 809,79 & $1.188,52$ & 5,83 & 14,95 & $1.209,30$ \\
\hline Gaziantep & $1.103,83$ & 6,17 & 13,49 & $1.123,50$ & $2.092,05$ & 10,48 & 26,11 & $2.128,63$ \\
\hline Hatay & 827,56 & 4,99 & 10,02 & 842,58 & $1.687,95$ & 8,73 & 20,97 & $1.717,65$ \\
\hline İstanbul & $9.511,71$ & 55,58 & 119,06 & $9.686,36$ & $13.993,33$ & 61,99 & 182,12 & $14.237,44$ \\
\hline İzmir & $3.239,81$ & 21,90 & 38,34 & $3.300,06$ & $4.731,84$ & 24,86 & 59,13 & $4.815,82$ \\
\hline Kahramanmaraş & 572,65 & 4,50 & 6,33 & 583,47 & 905,59 & 7,63 & 9,76 & 922,98 \\
\hline Kayseri & 953,66 & 6,79 & 10,93 & 971,38 & $1.428,10$ & 10,03 & 16,46 & $1.454,59$ \\
\hline Kocaeli & $1.469,79$ & 7,74 & 18,46 & $1.495,98$ & $2.852,23$ & 12,55 & 36,58 & $2.901,36$ \\
\hline Konya & $1.722,95$ & 11,40 & 20,13 & $1.754,48$ & $2.890,76$ & 16,74 & 34,83 & $2.942,33$ \\
\hline Malatya & 461,98 & 2,77 & 5,54 & 470,29 & 579,91 & 4,04 & 6,71 & 590,67 \\
\hline Manisa & 936,38 & 6,65 & 10,84 & 953,88 & $2.047,87$ & 11,30 & 25,06 & $2.084,23$ \\
\hline Mardin & 146,23 & 1,24 & 1,58 & 149,06 & 526,60 & 2,28 & 6,71 & 535,59 \\
\hline Mersin & $1.984,85$ & 8,84 & 25,34 & $2.019,03$ & $3.026,15$ & 13,07 & 38,66 & $3.077,88$ \\
\hline Muğla & 977,50 & 6,42 & 11,82 & 995,73 & $1.556,96$ & 9,38 & 19,08 & $1.585,42$ \\
\hline Ordu & 355,75 & 2,50 & 4,12 & 362,37 & 551,42 & 3,47 & 6,58 & 561,47 \\
\hline Sakarya & 836,14 & 5,81 & 9,69 & 851,64 & $1.169,10$ & 8,44 & 13,38 & $1.190,91$ \\
\hline Samsun & 977,50 & 5,58 & 11,88 & 994,96 & $1.551,40$ & 8,13 & 19,15 & $1.578,68$ \\
\hline Şanlıurfa & 485,02 & 5,07 & 4,75 & 494,84 & $1.169,90$ & 8,86 & 13,06 & $1.191,82$ \\
\hline Tekirdağ & 893,06 & 3,81 & 11,65 & 908,52 & $1.283,41$ & 5,52 & 16,65 & $1.305,58$ \\
\hline Trabzon & 564,25 & 2,84 & 7,06 & 574,15 & 853,68 & 3,56 & 11,03 & 868,27 \\
\hline Van & 137,87 & 1,22 & 1,51 & 140,60 & 329,07 & 2,25 & 3,85 & 335,18 \\
\hline Toplam & $42.620,02$ & 269,85 & 513,14 & $43.403,00$ & $69.045,89$ & 368,67 & 857,30 & $70.271,86$ \\
\hline Ortalama & & & & $1.446,77$ & & & & $2.342,40$ \\
\hline
\end{tabular}

2010 ve 2019 yıllarında büyükşehirlerdeki sera gazı emisyon miktarının daha kolay anlaşılabilmesi için veriler Şekil 8 ve Şekil 9'da Türkiye haritası üstünde gösterilmiştir.

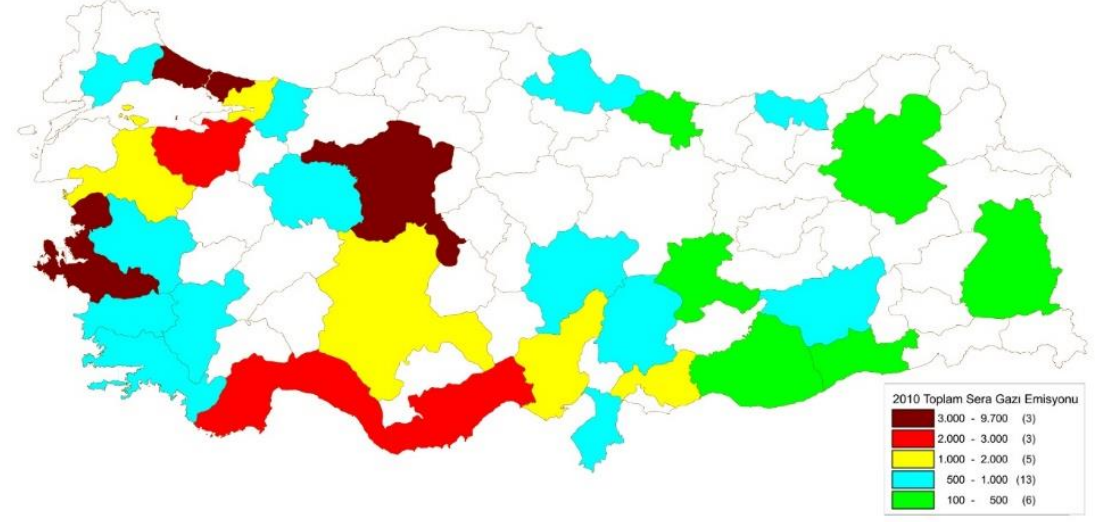

Şekil 8: 2010 yılında büyükşehirlerin karayolu kaynaklı toplam sera gazı emisyon miktarları (Gg COze.) 


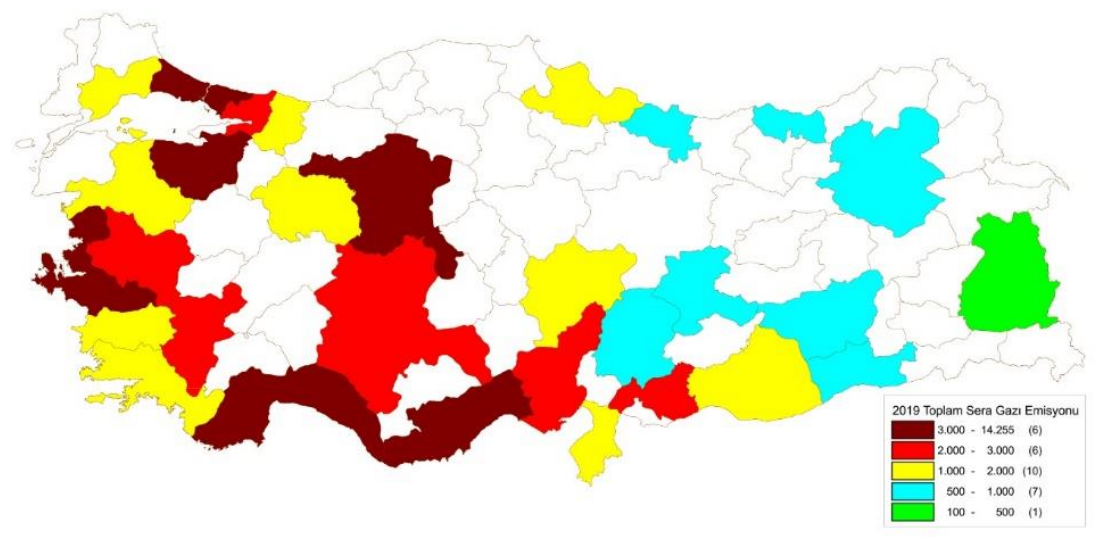

Şekil 9: 2019 yılında büyükşehirlerin karayolu kaynaklı toplam sera gazı emisyon miktarları (Gg CO $\mathrm{CO}_{2}$.)

Şekil 8 ve 9 incelendiğinde Antalya, Bursa ve Mersin'de sera gazı emisyonunun $3.000 \mathrm{Gg} \mathrm{CO}_{2}$ e.'in üstüne, Konya, Kocaeli, Adana, Gaziantep ve Balıkesir'de $2.000 \mathrm{Gg} \mathrm{CO}_{2}$ e.’in üstüne çıktığı görülmektedir. Muğla'daki emisyon miktarı 2010 yılında $1.000 \mathrm{Gg} \mathrm{CO}_{2} \mathrm{e}$.'in altında iken, 2019 yılında $2.000 \mathrm{Gg} \mathrm{CO}_{2}$ e.'in üstüne çıkmıştır. 2010 yılında emisyon miktarı $1.000 \mathrm{Gg} \mathrm{CO}_{2}$ e.'in altında olan sırasıyla Samsun, Kayseri, Manisa, Tekirdağ, Denizli, Sakarya, Hatay Eskişehir, Aydın ve Kahramanmaraş'ın 2019 yılında emisyon miktarı 1.000 Gg CO 2 e.'in üstüne çıkmıştır. Oransal değişim değerlendirildiğinde ise en fazla artış \%259 ile Mardin'de, \%140 ile Şanlıurfa'da, \%138 ile Van'da, \%104 ile Kahramanmaraş'ta ve \%101 ile Muğla'dadır. En az artış ise \%25 ile Malatya'da, \%43 ile Erzurum'da, \%46 ile İzmir'de ve \%47 ile İstanbul'dadır. 2010-2019 yılları arasında 30 Büyükşehirde toplam sera gazı emisyon miktarı \%61,97 oranında artmiştır.

Büyükşehirlerde gerçekleşen kişi başına, araç başına ve $\mathrm{km}^{2}$ 'ye düşen sera gazı emisyon miktarları Tablo 6'da verilmiştir.

Tablo 6: Büyükşehirlerde kişi başına, araç başına ve km²'ye düşen sera gazı emisyon miktarları (Gg CO $2 e$.

\begin{tabular}{|c|c|c|c|c|c|c|c|c|c|}
\hline & \multicolumn{3}{|c|}{ Kişi Başına Düşen x10-4 } & \multicolumn{3}{|c|}{ Araç Başına Düşen x10 ${ }^{-4}$} & \multicolumn{3}{|c|}{$\mathrm{Km}^{2}$ 'ye Düşen x10 ${ }^{-4}$} \\
\hline & 2010 & 2019 & Değişim \% & 2010 & 2019 & Değișim \% & 2010 & 2019 & Değișim \% \\
\hline Adana & 6,52 & 9,00 & 38,02 & 40,53 & 38,55 & $-4,89$ & 982 & 1454 & 48,13 \\
\hline Ankara & 9,96 & 14,53 & 45,78 & 38,06 & 41,49 & 9,03 & 1855 & 3196 & 72,28 \\
\hline Antalya & 10,45 & 11,97 & 14,59 & 42,93 & 37,17 & $-13,42$ & 1024 & 1490 & 45,48 \\
\hline Aydın & 8,13 & 12,10 & 48,89 & 39,74 & 41,65 & 4,82 & 991 & 1657 & 67,11 \\
\hline Balıkesir & 9,40 & 14,03 & 49,16 & 45,46 & 47,28 & 4,00 & 743 & 1182 & 59,03 \\
\hline Bursa & 7,85 & 11,12 & 41,64 & 43,19 & 42,65 & $-1,24$ & 1892 & 3143 & 66,14 \\
\hline Denizli & 9,57 & 19,30 & 101,77 & 41,77 & 59,31 & 41,99 & 735 & 1650 & 124,59 \\
\hline Diyarbakır & 3,42 & 4,57 & 33,62 & 59,49 & 72,61 & 22,05 & 345 & 530 & 53,49 \\
\hline Erzurum & 5,09 & 7,26 & 42,69 & 50,44 & 47,94 & $-4,94$ & 157 & 221 & 41,39 \\
\hline Eskişehir & 10,59 & 13,63 & 28,66 & 49,90 & 47,50 & $-4,81$ & 580 & 866 & 49,33 \\
\hline Gaziantep & 6,61 & 10,29 & 55,72 & 50,38 & 53,56 & 6,31 & 1651 & 3129 & 89,46 \\
\hline Hatay & 5,69 & 10,54 & 85,29 & 42,98 & 51,06 & 18,80 & 1525 & 3109 & 103,86 \\
\hline İstanbul & 7,31 & 9,17 & 25,55 & 37,07 & 37,02 & $-0,15$ & 17737 & 26071 & 46,98 \\
\hline İzmir & 8,36 & 11,03 & 31,95 & 41,41 & 41,65 & 0,57 & 2775 & 4050 & 45,93 \\
\hline Kahramanmaraş & 5,58 & 8,00 & 43,21 & 48,68 & 43,13 & $-11,39$ & 402 & 636 & 58,19 \\
\hline Kayseri & 7,87 & 10,34 & 31,36 & 42,03 & 40,45 & $-3,76$ & 572 & 857 & 49,74 \\
\hline Kocaeli & 9,59 & 14,86 & 54,93 & 67,71 & 78,87 & 16,48 & 4404 & 8541 & 93,94 \\
\hline Konya & 8,71 & 13,18 & 51,29 & 44,43 & 47,72 & 7,41 & 430 & 720 & 67,70 \\
\hline Malatya & 6,35 & 7,38 & 16,25 & 48,54 & 35,66 & $-26,54$ & 384 & 482 & 25,60 \\
\hline Manisa & 6,91 & 14,47 & 109,23 & 36,15 & 51,16 & 41,53 & 715 & 1563 & 118,50 \\
\hline Mardin & 2,00 & 6,39 & 218,97 & 32,19 & 79,03 & 145,52 & 170 & 610 & 259,32 \\
\hline Mersin & 12,25 & 16,72 & 36,50 & 72,31 & 65,71 & $-9,12$ & 1261 & 1922 & 52,44 \\
\hline Muğla & 12,18 & 16,13 & 32,40 & 47,38 & 46,47 & $-1,93$ & 787 & 1253 & 59,22 \\
\hline Ordu & 5,04 & 7,44 & 47,75 & 46,75 & 43,43 & $-7,10$ & 618 & 958 & 54,94 \\
\hline Sakarya & 9,76 & 11,57 & 18,55 & 55,44 & 46,79 & $-15,61$ & 1765 & 2469 & 39,84 \\
\hline Samsun & 7,94 & 11,71 & 47,39 & 48,73 & 49,16 & 0,88 & 1023 & 1623 & 58,67 \\
\hline Şanlıurfa & 2,97 & 5,75 & 93,20 & 35,16 & 64,57 & 83,64 & 257 & 619 & 140,85 \\
\hline Tekirdă̆ & 11,38 & 12,37 & 8,67 & 67,06 & 54,67 & $-18,48$ & 1468 & 2109 & 43,70 \\
\hline Trabzon & 7,52 & 10,73 & 42,77 & 54,95 & 45,73 & $-16,77$ & 1241 & 1876 & 51,23 \\
\hline Van & 1,36 & 2,95 & 117,13 & 23,06 & 45,68 & 98,04 & 67 & 160 & 138,38 \\
\hline Ortalama & 7,72 & 10,87 & 40,83 & 43,01 & 44,64 & 3,77 & 1087 & 1760 & 61,91 \\
\hline
\end{tabular}

Tablo 6'daki veriler $\mathrm{Gg} \mathrm{CO}_{2} \mathrm{e}$. biriminde çok küçük olduğu için $10^{-4}$ ile çarpılmıştır. Burada bahsi geçen rakamların gerçek değerlerine ulaşmak için $10^{4}$ e bölünmesi gerekmektedir. 30 büyükşehirde 2010 yılında kişi başına düşen karbon emisyonu miktarı 7,72 $\mathrm{Gg} \mathrm{CO}_{2} \mathrm{e}$. iken, 2019 yılında 10,87 $\mathrm{Gg} \mathrm{CO}_{2}$ e.'e yükselmiş ve \%40,83'luk bir artış gerçekleşmiştir. 
Yine 30 Büyükşehirde 2010 yılında araç başına düşen karbon emisyon miktarı 43,01 Gg CO 2 e. iken, 2019 yılında 44,64 $\mathrm{Gg} \mathrm{CO}_{2}$ e.'e yükselmiş ve \%3,77 oranında artmıştır. $\mathrm{Km}^{2}$ 'ye düşen emisyon miktarı ise 2010 yılında $1087 \mathrm{Gg} \mathrm{CO}_{2} \mathrm{e}$. iken, 2019 yılında $1760 \mathrm{Gg} \mathrm{CO}_{2} \mathrm{e}$.'e yükselmiş ve \%61,91'lik bir artış gerçekleşmiştir.

2010 ve 2019 yılları arasında kişi başına düşen sera gazı emisyon miktarındaki değişim Şekil 10 ve 11 'de gösterilmiştir.

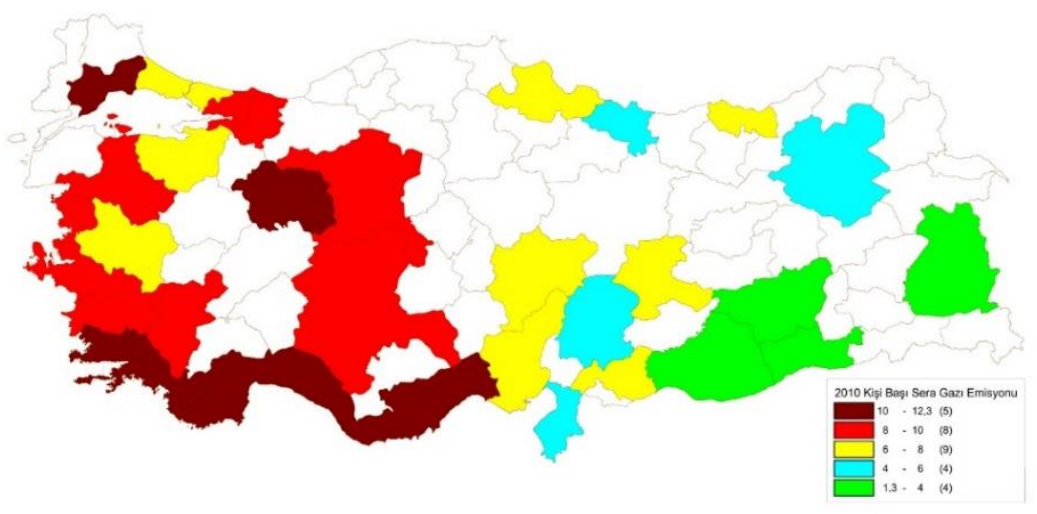

Şekil 10: 2010 yılında büyükşehirlerin karayolu kaynaklı kişi başına düşen sera gazı emisyon miktarları (Gg $\left.\mathrm{CO}_{2} \mathrm{e}.\right)$

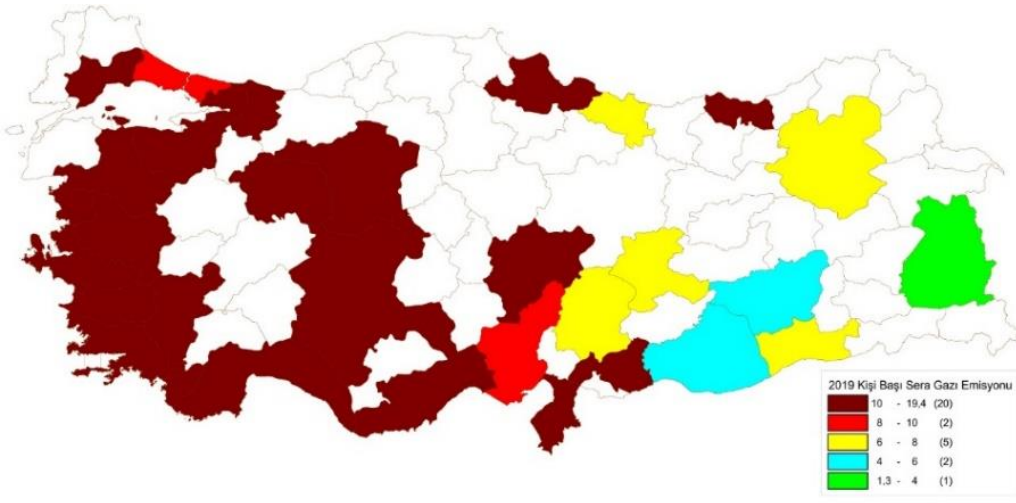

Şekil 11: 2019 yılında büyükşehirlerin karayolu kaynaklı kişi başına düşen sera gazı emisyon miktarları $\left(G g C_{2} e.\right)$

Şekil 10 ve 11 incelendiğinde, 2010 yılında kişi başına düşen en fazla sera gazı emisyonu sırasıyla Mersin, Muğla, Tekirdağ, Eskişehir ve Antalya'dadır. En az emisyon ise sırasıyla Van, Mardin, Şanlıurfa ve Diyarbakır'dadır. 2019 yılında ise kişi başına düşen en fazla sera gazı emisyonu sırasıyla Denizli, Mersin, Muğla, Kocaeli, Ankara ve Manisa'dadır. En az emisyon ise sırasıyla Van, Diyarbakır, Şanlıurfa, Mardin ve Erzurum'dadır. 2010 yılında 10 Gg $\mathrm{CO}_{2}$ e. üstünde 5 şehir bulunurken 2019 yılında bu sayı 20’ye çıkmıştır. 2010-2019 yılları arasında kişi başına düşen emisyon miktarı Mardin'de \%219, Van'da \%117, Manisa'da \%109 ve Denizli'de \%101 oranında artmıştır. Yine bu yıllar arasındaki en az değişim \%8,67 ile Tekirdağ, \%14,59 ile Antalya, \%16,25 ile Malatya, \%18,55 ile Sakarya ve \%25,55 ile İstanbul'da gerçekleşmiştir. 2010 ve 2019 yılları arasında araç başına düşen sera gazı emisyon miktarındaki değişim Şekil 12 ve 13'de gösterilmiştir.

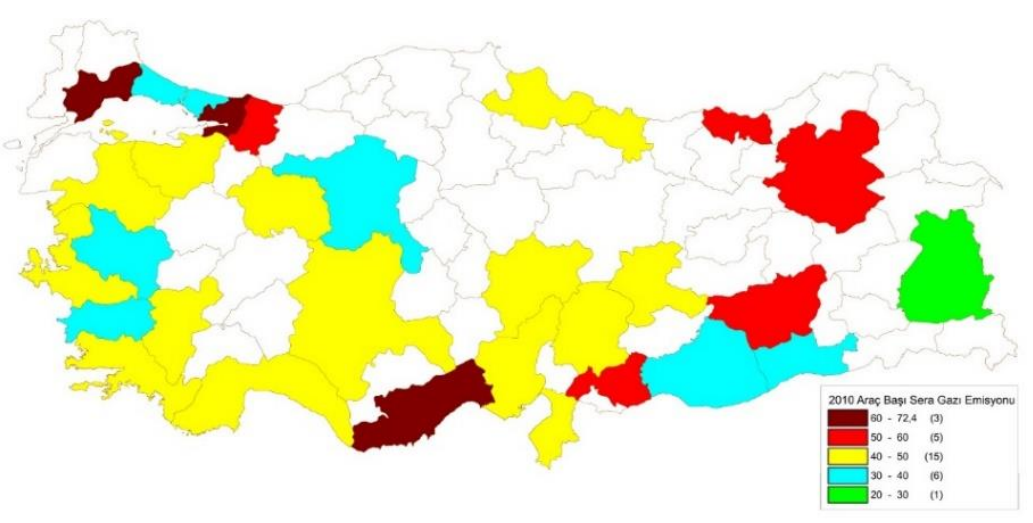

Şekil 12: 2010 yılında büyükşehirlerin karayolu kaynaklı araç başına düşen sera gazı emisyon miktarları (Gg $\mathrm{CO}_{2} \mathrm{C}$.) 


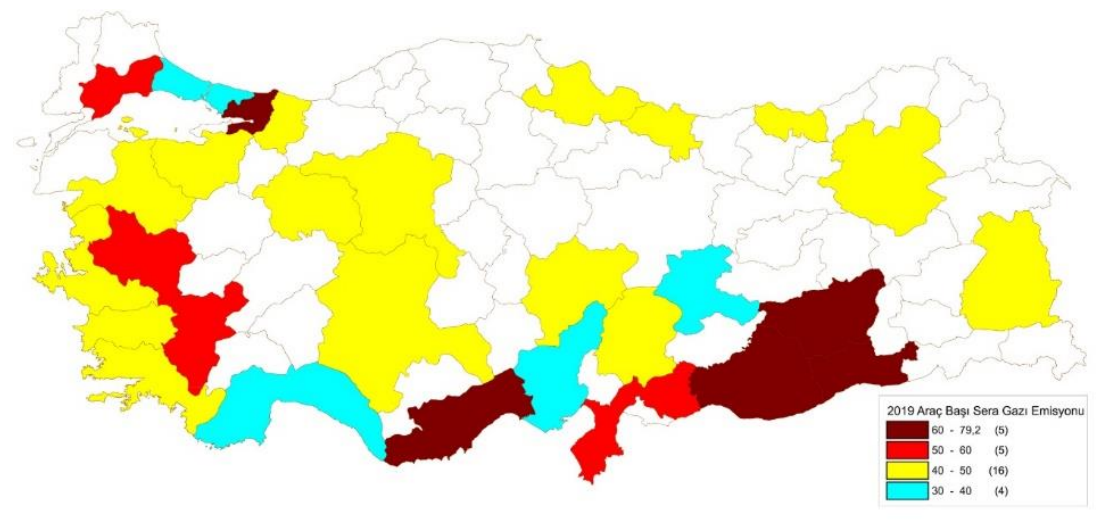

Şekil 13: 2019 yılında büyükşehirlerin karayolu kaynaklı araç başına düşen sera gazı emisyon miktarları (Gg CO$\left.{ }_{2} e.\right)$

Şekil 12 ve 13 incelendiğinde 2010 yılında araç başına düşen en fazla sera gazı emisyon miktarının gerçekleştiği şehirler sırasıyla Mersin, Kocaeli ve Tekirdağ'dır. En az emisyon ise sırasıyla Van, Mardin, Şanlıurfa, Manisa ve İstanbul'dadır. 2019 yılı incelendiğinde ise en fazla emisyon sırasıyla Mardin, Kocaeli, Diyarbakır, Mersin ve Şanlıurfa'dadır. En az emisyonun gerçekleştiği şehirler ise sırasıyla Malatya, İstanbul, Antalya, Adana, Kayseri ve Ankara'dır. 2010-2019 yı1ları arasındaki değişim oranlarına bakıldığında 15 şehirde artış yaşandığı, 15 şehirde azalış meydana geldiği görülmektedir. En fazla artış \%145 ile Mardin, \%98 ile Van ve \%83 ile Şanlıurfa'dadır. En fazla azalış ise \%26,54 ile Malatya, \%18,48 ile Tekirdağ ve \%16,77 ile Trabzon'dadır. İstanbul'da \%0,15 azalış, İzmir'de \%0,57 ve Ankara'da \%9,03 oranında artış gerçekleşmiştir.

2010 ve 2019 yılları arasında km² ye düşen sera gazı emisyon miktarındaki değişim Şekil 14 ve 15 ’te gösterilmiştir.

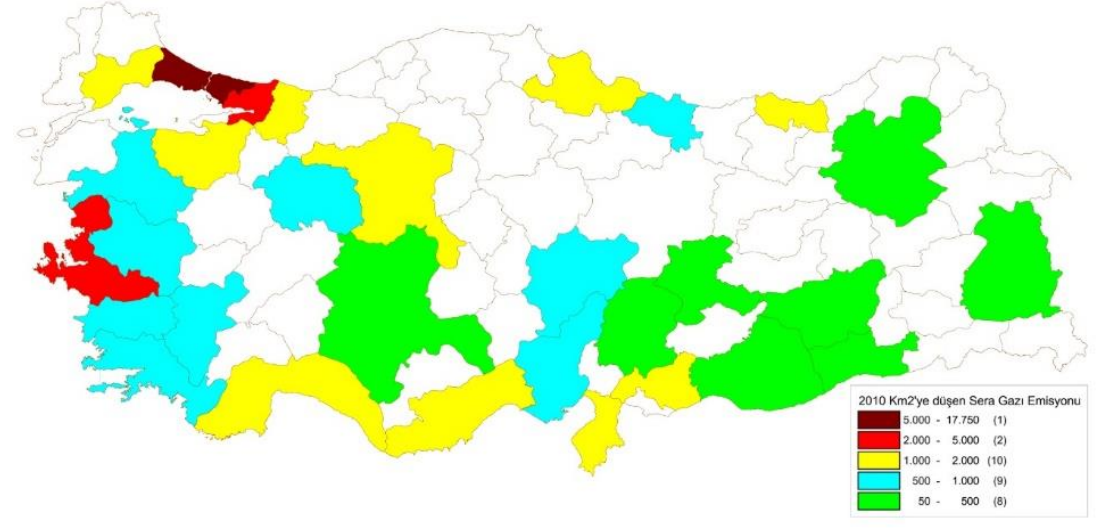

Şekil 14: 2010 yılında büyükşehirlerde karayolu kaynaklı km²'ye düşen sera gazı emisyon miktarları (Gg COze.)

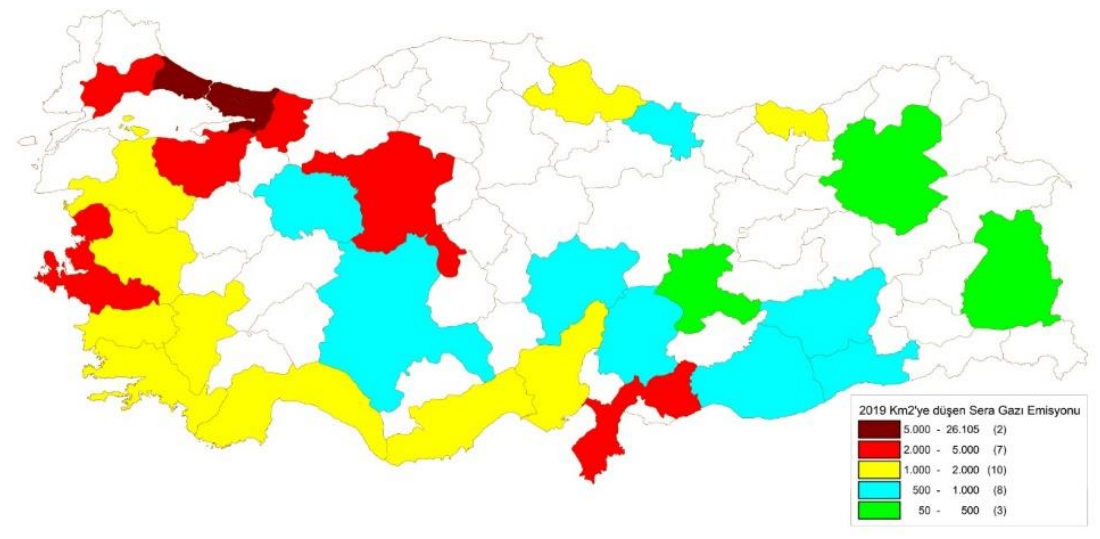

Şekil 15: 2019 yılında büyükşehirlerde karayolu kaynaklı km²'ye düşen sera gazı emisyon miktarları (Gg COze.) 
Şekil 14 ve 15 incelendiğinde 2010 yılında $\mathrm{km}^{2}$ 'ye düşen en fazla sera gazı emisyonu İstanbul'da gerçekleşmiştir. İstanbul'u sırasıyla Kocaeli, İzmir, Bursa ve Ankara izlemektedir. En az emisyon ise sirasıyla Van, Erzurum, Mardin ve Şanlıurfa'dadır. 2019 yılında ise $\mathrm{km}^{2}$ 'ye düşen en fazla sera gazı emisyonu sırasıyla İstanbul, Kocaeli, İzmir, Ankara ve Bursa'dadır. En az emisyon ise sırasıyla Van, Erzurum, Malatya ve Diyarbakır'dadır. 2010-2019 yılları arasında km²'ye düşen emisyon miktarındaki en fazla artış \%259 ile Mardin, \%140 ile Şanlıurfa, \%138 ile Van, \%124 ile Denizli ve \%118 ile Manisa'da gerçekleşmiştir. En az artış ise \%25 ile Malatya, \%39 ile Sakarya ve \%41 ile Erzurum’dadır. Diğer taraftan İzmir'de \%45, İstanbul'da \%46 ve Ankara'da \%72 oranında artmıştır.

Çalışmanın tüm bulguları 2019 yılındaki sonuçlara göre sıralanarak Şekil 16, Şekil 17, Şekil18 ve Şekil 19'da verilmiştir. Şekiller incelendiğinde İstanbul, Ankara ve İzmir'de toplam sera gazı emisyon miktarı yüksek olmasına karşın, kişi başına düşen sera gazı emisyon miktarında Denizli, Mersin ve Muğla'nın, araç başına düşen sera gazı emisyon miktarında Mardin, Kocaeli ve Diyarbakır'ın, $\mathrm{km}^{2}$ ye düşen sera gazı emisyon miktarında ise İstanbul, Kocaeli ve Hatay’ın yüksek olduğu görülmektedir.

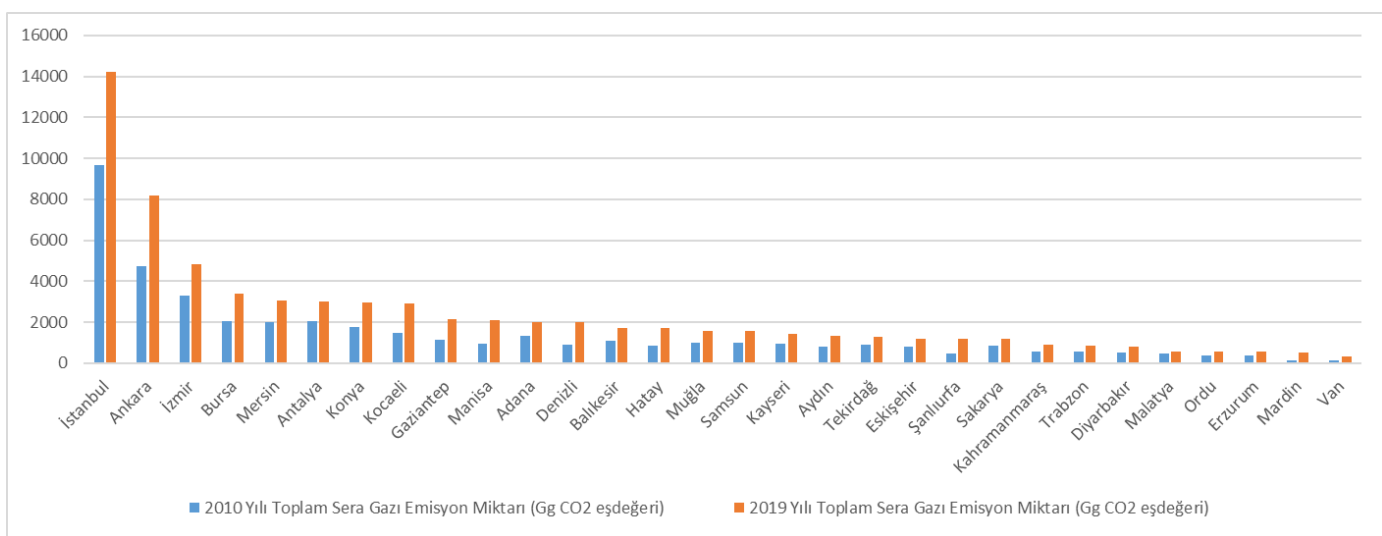

Şekil 16: 2010-2019 yıllarında büyükşehirlerin karayolu kaynaklı toplam sera gazı emisyon miktarları

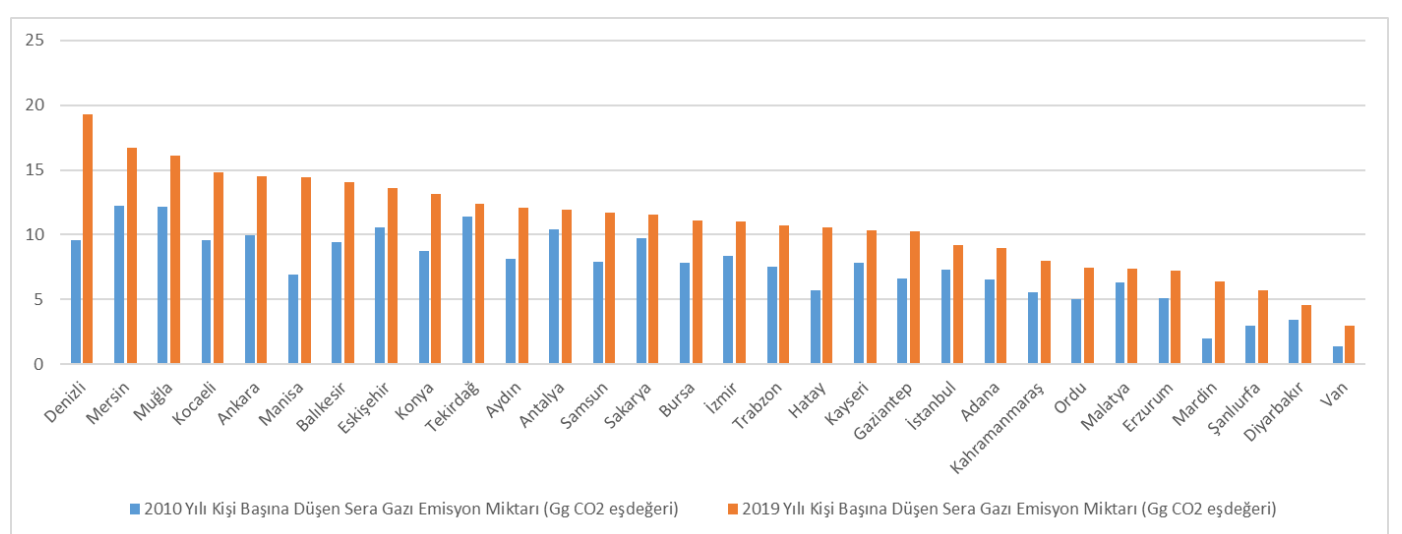

Şekil 17: 2010-2019 yıllarında büyükşehirlerde karayolu kaynaklı kişi başına düşen sera gazı emisyon miktarları

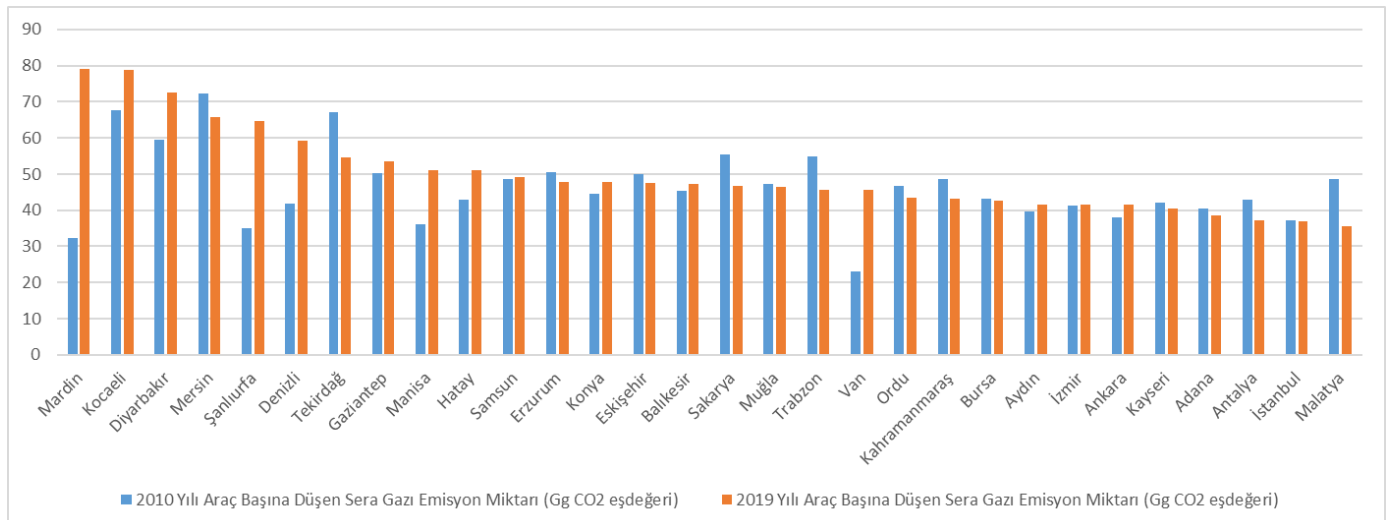

Şekil 18: 2010-2019 yıllarında büyükşehirlerde karayolu kaynaklı araç başına düşen sera gazı emisyon miktarları 


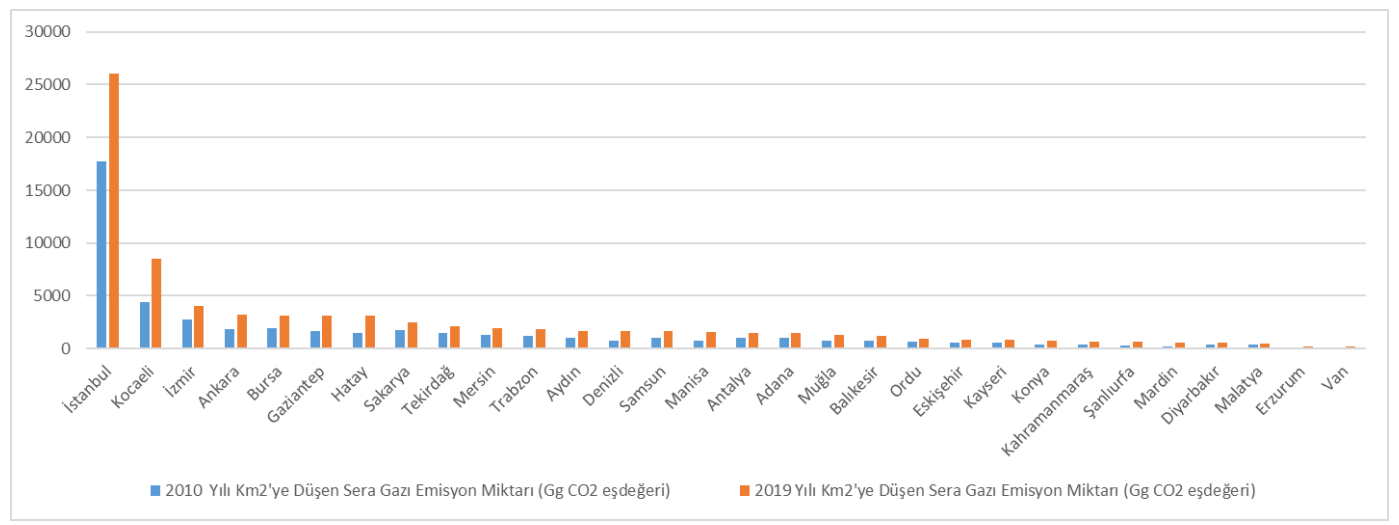

Şekil 19: 2010-2019 yıllarında büyükşehirlerde karayolu kaynaklı km²'ye düşen sera gazı emisyon miktarları

2010-2019 yılları arasında sera gazı emisyon miktarındaki değişimin hızı Şekil 20'de verilmiştir. En hızlı artış Mardin, Van ve Şanlıurfa şehirlerinde yaşanırken, Malatya, Tekirdağ ve Sakarya'da artış hızının diğer şehirlere göre yavaş olduğu görülmektedir.

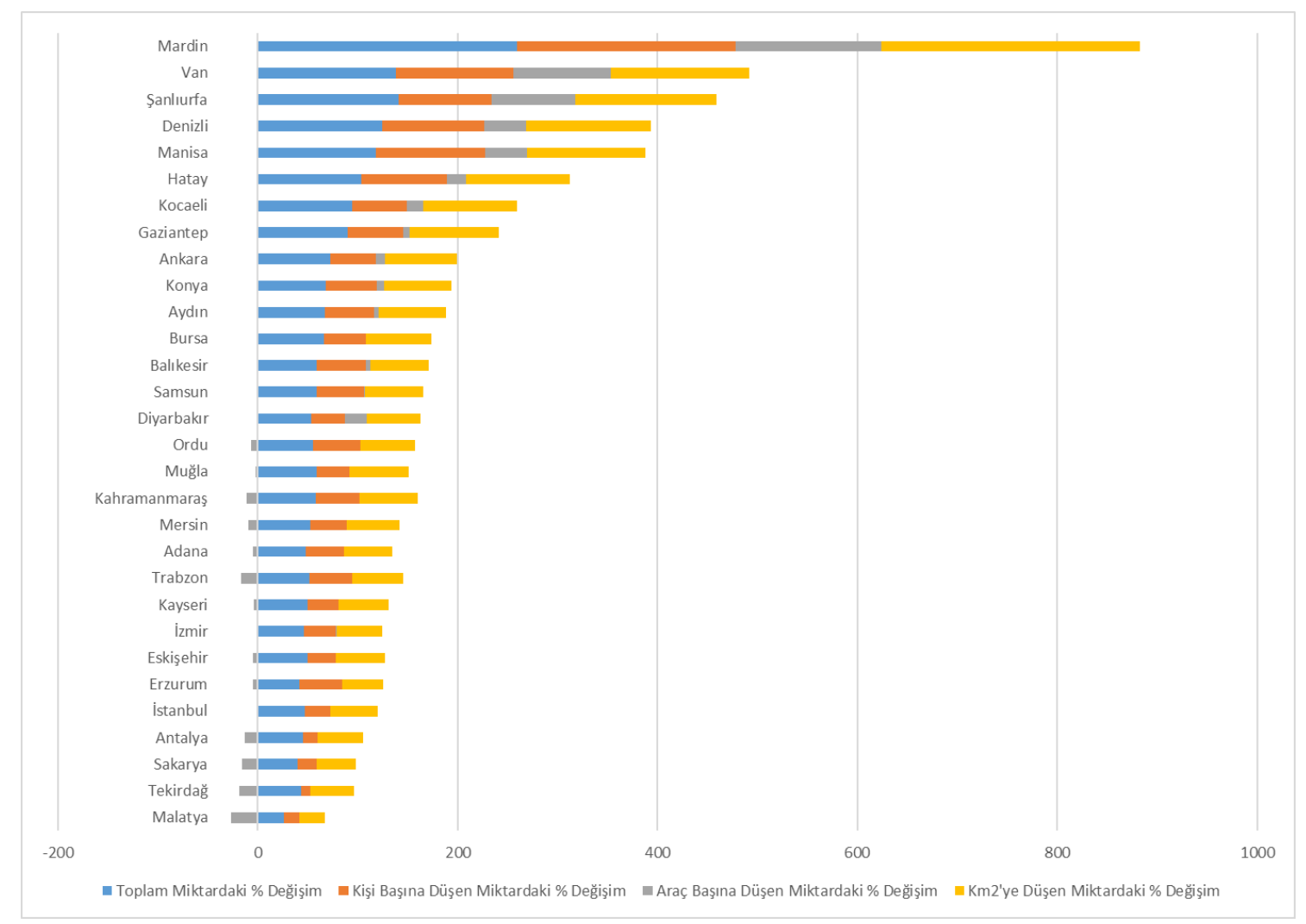

Şekil 20 : 2010-2019 yılları arasında sera gazı emisyon miktarındaki değişimin hızı

Tablo 4'te sözü geçen tüm alternatif taşıma seçenekleri ve alt yapıların sadece İstanbul ve Ankara'da olduğu görülmektedir. Muğla, Ordu ve Trabzon şehirlerinde hiçbirisi bulunmamakta, dokuz şehirde ise sadece demiryolu bağlantısı bulunmaktadır. Büyükşehirlerde 2010-2019 yılları arasındaki sera gazı emisyon değişim oranları bahsi geçen her bir alternatif taşıma seçeneği ve alt yapının olduğu ve olmadığı şehirler karşılaştırılarak tablo 7'de verilmiştir. 
Tablo 7: Taşıma seçenekleri ve alt yapıya göre toplam ve kişi başına düşen sera gazı emisyonu değişim oranı

\begin{tabular}{|c|c|c|c|c|c|c|}
\hline & \multicolumn{2}{|c|}{ Şehir Sayısı } & \multicolumn{2}{|c|}{$\begin{array}{l}\text { Toplam Emisyon Miktarı } \\
\text { Ortalama Değişim \% }\end{array}$} & \multicolumn{2}{|c|}{$\begin{array}{l}\text { Kişi Başına Düşen Emisyon } \\
\text { Miktarı Ortalama Değişim \% }\end{array}$} \\
\hline & Var & Yok & Var & Yok & Var & Yok \\
\hline Metro/HRS & 5 & 25 & 54,40 & 78,14 & 37,74 & 56,97 \\
\hline YHT & 6 & 24 & 61,68 & 77,31 & 37,46 & 57,84 \\
\hline Banliyö/Tramvay & 10 & 20 & 62,70 & 79,92 & 38,15 & 61,57 \\
\hline Lojistik Merkez & 10 & 20 & 65,69 & 78,43 & 47,56 & 56,86 \\
\hline Demiryolu & 25 & 5 & 77,94 & 55,40 & 57,35 & 35,83 \\
\hline
\end{tabular}

Tablo 7 incelendiğinde Metro veya HRS'nin 5 şehirde kullanıldığı ve 25 şehirde olmadığı görülmektedir. 2010-2019 yılları arasında Metro veya HRS kullanılan şehirlerde toplam sera gazı emisyon miktarı \%54,40 oranında artarken, olmayan 25 şehirde bu oran \% 78,14 olarak gerçekleşmiştir. Metro veya HRS kullanılan şehirlerde kişi başına düşen sera gazı emisyon miktarı \%37,74 artarken, olmayan şehirlerde bu artış \%56,97'dir. 6 büyükşehirde YHT bağlantısı bulunmaktadır. YHT bağlantısı bulunan büyükşehirlerde toplam emisyon miktarı $\% 61,68$ oranında artarken, bağlantısı olmayan şehirlerde bu oran \%77,31'dir. Kişi başına düşen emisyon miktarı YHT bağlantısı olan şehirlerde \%37,46 oranında artarken, bağlantısı olmayan şehirlerde artış \%57,84'dür. Banliyö veya Tramvay ise 10 büyükşehirde kullanılmaktadır. Bu şehirlerdeki 2010-2019 yılları arasında toplam emisyon miktarı \%62,70 oranında artarken, olmayan şehirlerde $\% 79,92$ oranında artmıştır. Banliyö veya tramvay olan şehirlerde kişi başına düşen emisyon miktarı \%38,15 oranında artarken, olmayan şehirlerde artış \%61,57'dir. Lojistik merkez ise 2019 yılı sonu itibariyle 10 büyükşehirde aktif durumdadır. Bu şehirlerdeki toplam sera gazı emisyon miktarı \%65,69 artarken, olmayan şehirlerde \% 78,43 oranında artış gerçekleşmiştir. Kişi başına düşen emisyon miktarı lojistik merkez olan şehirlerde \%47,56 oranında artarken, olmayan şehirlerde bu oran \%56,86'dır. Demiryolu bağlantısı ise 25 büyükşehirde bulunmaktadır. Bu şehirlerde toplam emisyon miktarı \%77,94 artarken, olmayan şehirlerde ise artış \%55,40’tır. Kişi başına düşen emisyon miktarındaki artış demiryolu bağlantısı olan şehirlerde \%57,35 iken, olmayan şehirlerde \%35,83 oranında gerçekleşmiştir.

\section{Sonuç}

Avrupa Birliği (AB) İklim ve Enerji Paketinde 2020 y1lındaki emisyon miktarının 1990'na göre \%20 azaltma taahhüdünde bulunmuştur (Çipil 2014). İklim Saati verilerine göre AB'de 1990'da emisyon miktarı 4,28 Gt $\mathrm{CO}_{2} \mathrm{e}$. iken 2018'de 3,33 $\mathrm{Gt} \mathrm{CO}_{2}$ e. olarak gerçekleşmiş ve \%22,19'luk bir azaltım sağlanmıştır (Climate Watch 2021a). Türkiye'de ise 1990-2018 yılları arasında \% 150,36'lık bir artış yaşanmıştır (Climate Watch 2021b). Türkiye 2015 yllında Birleşmiş Milletler İklim Değişikliği Çerçeve Sözleşmesinde (UNFCCC) iklim taahhüdünde bulunarak ulusal katkı beyanı sunmuştur (Timperley 2018). Bu beyanda Türkiye, 2021'den 2030'a kadar belirlenen baz senaryo üzerinden \%21'e varan oranda azaltım yapacağını taahhüt etmektedir (INDC of Turkey 2015). Baz senaryoya göre 2030 yılında Türkiye'nin sera gazı emisyon miktarı 1,175 $\mathrm{Mt} \mathrm{CO}_{2} \mathrm{e}$. olarak hesaplanmıştır (Timperley 2018). Türkiye taahhüdünü yerine getirebilirse bu emisyonların $928,25 \mathrm{Mt} \mathrm{CO}_{2} \mathrm{e}$. olmasi beklenmektedir.

Bu çalışmada 2019 yılı itibariyle büyükşehir statüsündeki şehirlerin 2010 ve 2019 yıllarına ait karayolu kaynaklı sera gazı emisyon miktarları IPCC tarafindan geliştirilen Tier 1 yöntemi kullanılarak hesaplanmışıtır. Elde edilen sonuçlara göre 30 büyükşehirde 2010 yılında toplam sera gazı emisyon miktarı $43.403 \mathrm{Gg} \mathrm{CO}_{2}$ e. iken, 2019 yılında önemli miktarda artarak $70.271 \mathrm{Gg} \mathrm{CO}_{2} \mathrm{e}$. ulaşmıştır. 2010-2019 yılları arasında toplam sera gazı emisyon miktarı \% 61,97 oranında artmıştır. 2010 -2019 yılları arasında kişi başına düşen emisyon miktarı \%40,83, araç başına düşen emisyon miktarı \%3,77 ve $\mathrm{km}^{2}$ ye düşen emisyon miktarı \%61,90 oranında arttığı tespit edilmiştir.

TUIK verilerine göre Türkiye'de 2010 yılında toplam sera gazı emisyon miktarı 398,9 $\mathrm{Mt} \mathrm{CO}_{2} \mathrm{e}$. iken 2018 yılında 520,9 Mt CO 2 e. çıkarak \%30,58 artmıştır (TUiK 2021). Yıllık artış \%3,82 olarak gerçekleşmiştir. Çalışmamızın sonuçlarına göre Türkiye'de 2010 yılındaki toplam sera gazı emisyonunun \%10,88'i büyükşehirlerdeki karayolu ulaşımından kaynaklanmaktadır. Büyükşehirlerdeki karayolu ulaşımından kaynaklı yıllık emisyon artış $\%$ 6,88 olup, toplam emisyon artışına göre çok daha yüksektir. Soylu (2007) 2004 yılında Türkiye'de karayolu kaynaklı emisyon $\left(\mathrm{CO}_{2}\right.$, $\mathrm{CH}_{4}, \mathrm{NO}_{2}$ gazlarına göre) miktarını $37.756 \mathrm{Gg} \mathrm{CO}_{2} \mathrm{e}$. olarak hesaplamıştır. Büyükşehirlerden kaynaklı emisyon miktarı 2004'deki Türkiye karayolu kaynaklı toplam emisyon miktarına göre 2010 yılında \%14,95, 2019 y1lında \%86,11 daha fazla gerçekleşmiştir. Dolayısıyla Türkiye'de toplam ve karayolu kaynaklı sera gazı emisyon miktarının sürekli arttığı ve karayolu kaynaklı emisyon miktarının toplam içinde önemli bir payı olduğu görülmektedir.

Çalışmamızda İstanbul, Ankara, İzmir, Bursa, Mersin, Antalya, Konya ve Kocaeli’nin hem 2010 hem de 2019 yılında ortalama emisyon miktarını üstünde değerlere sahip olduğu tespit edilmiş̧ir. Dolayısıyla belirtilen 8 şehirde alınacak öncelikli önlemler ile ülkemizin toplam emisyon miktarı önemli oranda düşürülebilecektir. Toplam sera gazı emisyon miktarı değerlendirildiğinde en çok miktar; İstanbul, Ankara ve İzmir'de gerçekleşmesine rağmen yüzdesel artı̧̧ olarak İstanbul ve İzmir'in son sıralarda, Ankara'nın ise üst sıralarda yer alması dikkat çekmektedir. $\mathrm{Km}^{2}$ 'ye düşen emisyon miktarında Ankara \%72 artışla üst sıralarda yer alırken, İstanbul \%47, İzmir ise $\% 46$ artışla son sıralara yakın yerlerde bulunmaktadır. Dolayısıyla alınacak önlemlere Ankara'dan başlanması önerilmektedir. Büyükşehirlerin yarısında araç başına düşen emisyon miktarı azalmıştır. 
Taşıt sayılarının artmasına karşın taşıt başına düşen emisyon miktarının azalması yeni model taşıtların yakıt verimliliğinin yüksek olduğunu ve emisyon miktarının ise düşük olduğunu göstermektedir. Dolayısıyla çalışmamızın bulguları Işık ve Kilınç (2014) ve Mock (2016) tarafından bildirilen bulgularla örtüşmektedir. Çalışmada büyükşehirler alternatif taşıma seçenekleri ve alt yapıya sahip olma durumuna göre de değerlendirilmiştir. Söz konusu taşıma seçenekleri ve alt yapılar şehirlerdeki toplam emisyon miktarını azaltmamakta ancak artışın hızını yavaşlatmaktadır. Artış hızını en çok yavaşlatan taşıma seçeneği metro/HRS olarak belirlenmiştir. Cirit (2014) çalışmasında emisyon miktarı en düşük taşıma seçeneklerini metro ve HRS olarak belirlemiştir. Çalışmamızın bu bulgusu Cirit (2014)'in elde ettiği sonuçlarla örtüşmektedir. Çalışmada 2019 yılı itibariyle aktif olan 10 adet lojistik merkez değerlendirmeye alınmıştır. Ancak TCDD tarafından 2020 yılında devreye sokulan, yapımı devam eden ve proje aşamasındaki lojistik merkezler ile ilerleyen yıllarda emisyon miktarının artış hızı yavaşlatılabilecektir. Diğer taraftan demiryolu bağlantısı olan şehirlerdeki artış oranının olmayan şehirlere göre yüksek olması ülkemizde demiryolunun etkin ve verimli bir şekilde kullanılmadığını göstermektedir. Ülkemizde yurtiçi taşımacılıkta demiryolunun çok az tercih edilmesinin nedeni transit sürelerinin uzun olmasıdır. Demiryollarında elektrikli alt yapı ve duble hatlar ile transit süreleri kısaltılabilir. Yurtiçi taşımacılıktaki demiryolu payı artarken, emisyon miktarının düşmesine katkı sağlanabilir. Raylı sistemler ve altyapılar ile ilgili sonuçlar taşıma seçeneklerinin sera gazı emisyonu üzerindeki etkilerinin genel bir değerlendirmesini içermektedir. Daha kesin sonuçların elde edilebilmesi için yolcu sayıları/yolcu payları ve yük miktarı/yük payı gibi verilerle hesaplamaların yapılması önerilmektedir.

\section{Kaynaklar}

Alam M.S., Duffy P., Hyde B., McNabola A., (2017), Improvement in the estimation and back-extrapolation of $\mathrm{CO}_{2}$ emissions from the Irish road transport sector using a bottom-up data modelling approach, Transportation Research Part D: Transport and Environment, 56, 18-32.

Argun M.E., Ergüç R., Sarı Y., (2019), Konya/Selçuklu ilçesi karbon ayak izinin belirlenmesi, Selçuk Üniversitesi Mühendislik Bilim ve Teknoloji Dergisi, 7(2), 287-297.

Atmaca Ç., Sevimoğlu O. (2020), Şehir kaynaklı sera gazı emisyonunun belirlenmesi: Kocaeli ili örneği, Iğdır Üniversitesi Fen Bilimleri Enstitüsü Dergisi, 10(3), 1616-1627.

Baki R. (2018), Avrupa Birliği ülkeleri ile Türkiye'deki lojistik köy uygulamaları ve uygun kuruluş yeri seçimi, Adnan Menderes Üniversitesi Sosyal Bilimler Enstitüsü Dergisi, 5(2), 148-162.

Bıyık Y., Civelekoğlu G. (2018), Ulaşım sektöründen kaynaklı karbon ayak izi değişiminin incelenmesi, Bilge International Journal of Science and Technology Research, 2(2), 157-166.

Bıyık Y., Civelekoğlu G. (2020), Isparta ilinde karayolu kaynaklı karbon ayak izinin hesaplanmasl, Bilge International Journal of Science and Technology Research, 4(2), 78-87.

Cansız Ö.F., Ünsalan K., (2020), Yük taşımacılığında tek türlü ve çok türlü taşımacılık rotalarının karbon ayak izinin karşılaştırılması, Dicle Üniversitesi Mühendislik Fakültesi Mühendislik Dergisi, 11(2), 809-816.

Cirit F., (2014), Sürdürülebilir kentiçi ulaşım politikaları ve toplu taşıma sistemlerinin karşılaştırılması, Uzmanlık Tezi, T.C. Kalkınma Bakanlığ 1 , Ankara.

Climate Watch (2020), World greenhouse gas emissions in 2016 by sector, end use and gases, https://www.climatewatchdata.org/keyvisualizations?visualization=1, [Erişim 07 Aralık 2020].

Climate Watch, (2021a) Global Historical Emissions (European Union), https://www.climatewatchdata.org/ghgemissions? breakBy=regions\&end_year=2018\&regions=EUU\&source=CAIT\&start_year=1990, [Erişim 19 Mart 2021].

Climate Watch (2021b), Global Historical Emissions (G20), https://www.climatewatchdata.org/ghg-emissions?breakBy=countries\& end_year=2018\&regions=G20\&source=CAIT\&start_year=1990, [Erişim 19 Mart 2021].

Çevik O., Gülcan B., (2011), Lojistik faaliyetlerin çevresel sürdürülebilirliği ve Marco Polo programı, Karamanoğlu Mehmetbey Üniversitesi Sosyal ve Ekonomik Araştırmalar Dergisi, (1), 35-44.

Çipil F., (2014), Performance analysis of Turkey's transport sector greenhouse gas emissions. Energy \& Environment, 25(2), 357-367.

Dündar A.O., Kolay A., (2021), Karayolu yük ve yolcu taşımacılığının çevresel sürdürülebilirlik bakımından değerlendirilmesi ve Konya ili sera gazı emisyonunun hesaplanması, Ömer Halisdemir Üniversitesi İktisadi ve İdari Bilimler Fakültesi Dergisi, 14(1), 317-334.

Edenhofer Ottmar (Ed.). (2015), Climate change 2014: mitigation of climate change, Cambridge University Press.United States of America.

El-Fadel M., Bou-Zeid E. (1999), Transportation GHG emissions in developing countries.: the case of Lebanon, Transportation Research Part D: Transport and Environment, 4(4), 251-264.

Elgün M.N., Aşıkoğlu N.O., (2016), Lojistik köy kuruluş yeri seçiminde TOPSIS yöntemiyle merkezlerin değerlendirilmesi, Afyon Kocatepe Üniversitesi İktisadi ve İdari Bilimler Fakültesi Dergisi, 18(1), 161-170.

EPA, (2019), Global greenhouse gas emissions data, United States Environmental Protection Agency, https://www.epa.gov/ ghgemissions/global-greenhouse-gas-emissions-data, [Erişim 09 Ocak 2021].

EPDK, (2011b), Sıvılaş̧ııılmış petrol gazları (LPG) piyasası 2010 yılı sektör raporu, Enerji Piyasası Düzenleme Kurumu, https://www.epdk.gov.tr/Detay/DownloadDocument?id=Z35HY3UyDx8=, [Erişim 01 Aralık 2020].

EPDK, (2011a), Petrol piyasası sektör raporu 2010, Enerji Piyasası Düzenleme, Kurumu https://www.epdk.gov.tr/ Detay/DownloadDocument?id=WuVmeFaaXBw=, [Erişim 01 Aralık 2020].

EPDK, (2020a), Petrol piyasası 2019 yll sektör raporu, Enerji Piyasası Düzenleme Kurumu, https://www.epdk.gov.tr/ Detay/DownloadDocument?id=mBWzKsBr9Ds=, [Erişim 01 Aralık 2020].

EPDK, (2020b), Sıvılaştırılmış petrol gazları (LPG) piyasası 2019 yılı sektör raporu, Enerji Piyasası Düzenleme Kurumu, https://www.epdk.gov.tr/Detay/DownloadDocument?id=9XVhZjjrwqo=, [Erişim 01 Aralık 2020]. 
Eşitti B., Duran E., (2018), Çanakkale turizminin karbon ayak izi üzerine bir araştırma, Journal of Awareness, 3(5), 597-608.

Gonçalves D.N.S., Goes G.V., D'Agosto M.A., de Mello Bandeira R.A., (2019), Energy use and emissions scenarios for transport to gauge progress toward national commitments, Energy Policy, 135, 1-10.

Güzel T.D., Alp K., (2020), Modeling of greenhouse gas emissions from the transportation sector in Istanbul by 2050, Atmospheric Pollution Research, 11(12), 2190-2201.

Haksevenler H.G., Onat N.Ç., Akpinar B., Bedel T. (2020), Yerel yönetimler için karbon ayak izinin belirlenmesi: Ümraniye belediyesi örneği, Doğal Afetler ve Çevre Dergisi, 6(2), 319-333.

HGM, (2020), Il ve ilçe yüz ölçümleri, Harita Genel Müdürlüğü, https://www.harita.gov.tr/uploads/files/products/il-ve-ilceyuz olcumleri-103.pdf, [Erişim 07 Aralık 2020].

INDC of Turkey (2015). Republic Of Turkey Intended Nationally Determined Contribution, https://www4.unfccc.int/sites/ submissions/INDC/Published\%20Documents/Turkey/1/The INDC of TURKEY v.15.19.30.pdf, [Erişim 19 Mart 2021].

IPCC, (2006), 2006 guidelines for national greenhouse gas inventories, https://www.ipcc-nggip.iges.or.jp/public/2006gl/, [Erişim 01 Aralik 2020].

IPCC, (2006a), 2006 guidelines for national greenhouse gas inventories: methodological choice and identification of key categories, https://www.ipcc-nggip.iges.or.jp/public/2006gl/pdf/1_Volume1/V1_4_Ch4_MethodChoice.pdf, [Erişim 01 Aralık 2020].

IPCC, (2006b), 2006 guidelines for national greenhouse gas inventories: mobile combustion, https://www.ipccnggip.iges.or.jp/public/ 2006gl/pdf/2_Volume2/V2_3_Ch3_Mobile_Combustion.pdf, [Erişim 01 Aralık 2020].

IPCC, (2006c), 2006 guidelines for national greenhouse gas inventories: introduction, https://www.ipccnggip.iges.or.jp/public/ 2006gl/pdf/2_Volume2/V2_1_Ch1_Introduction.pdf, [Erişim 01 Aralık 2020].

IPCC, (2014), Climate change 2014 mitigation of climate change summary for policymakers technical summary, https://www.ipcc.ch/ site/assets/uploads/2018/03/WGIIIAR5_SPM_TS_Volume-3.pdf, [Erişim 01 Aralık 2020].

IPCC, (2015), Climate change 2014 synthesis report, https://ar5syr.ipcc.ch/ipcc/ipcc/resources/pdf/IPCC_SynthesisReport.pdf, [Erişim 01 Aralık 2020].

Işı1k N., Kılınç E.C., (2014), Ulaştırma sektöründe $\mathrm{CO}_{2}$ emisyonu ve enerji ar-ge harcamaları iliş̧kisi, Sosyoekonomi, 22(2), $321-346$.

Kim K., Ko H., Lee T., Kim D. (2011), Comparison of greenhouse gas emissions from road transportation of local government by calculation methods, Journal of Korean Society for Atmospheric Environment, 27(4), 405-415.

Li F., Cai B., Ye Z., Wang Z., Zhang W., Zhou P., Chen J. (2019), Changing patterns and determinants of transportation carbon emissions in Chinese cities, Energy, 174, 562-575.

Liao C., Lu C., Tseng P., (2011), Carbon dioxide emissions and inland container transport in Taiwan, Journal of Transport Geography, 19(4), 722-728.

Mehrotra S., Lefevre B., Zimmerman R., Gercek H., Jacob K., Srinivasan S., (2011), Climate change and urban transportation systems, Climate Change and Cities First Assessment Report of the Urban Climate Change Research Network'ün içinde (Rosenzweig C., Solecki W.D., Hammer S.A., Mehrotra S., Ed.) Cambridge University Press, New York. ss.145-177.

Mock P., (2016), Policy options to reduce emissions from the road transport sector in Turkey, IPM-Mercator Policy Brief, 1, 1-13.

Murphy P.R., Poist R.F., (2003), Green perspectives and practices: a "comparative logistics" study, Supply Chain Management: an International Journal, 8(2), 122-131.

Otken B., Gümüşay Ü., (2010), Karayolunda hareket halindeki tașıtların çevreye yaydıkları emisyonların analizi için CBS'de arayüzlerin hazırlanması, Jeodezi ve Jeoinformasyon Dergisi, https://dergipark.org.tr/tr/pub/hkmojjd/issue/53143/704648, [Erişim 9 Aralık 2020]

Öncü E., Özdemir Ö., (2020), Ekonomik büyüme ve ulaştırma altyapı kalitesinin $\mathrm{CO}_{2}$ emisyonuna etkisinin incelenmesi, Nişantaşı Üniversitesi Sosyal Bilimler Dergisi, 8(1), 45-54.

Özen M., Tuydes-Yaman H., (2013), Evaluation of emission cost of inefficiency in road freight transportation in Turkey, Energy Policy, 62, 625-636.

Pamučar D., Gigović L., Ćirović G., Regodić M., (2016), Transport spatial model for the definition of green routes for city logistics centers. Environmental Impact Assessment Review, 56, 72-87.

Pishvaee M.S., Torabi S., Razmi J. (2012), Credibility-based fuzzy mathematical programming model for green logistics design under uncertainty, Computers \& Industrial Engineering, 62(2), 624-632.

Ritchie H., Roser M. (2017), $\mathrm{CO}_{2}$ and greenhouse gas emissions, https://ourworldindata.org/emissions-by-sector, [Erișim 29 Aralık 2020]

Soruşbay C., (2007), Karayolu ulaşımından kaynaklanan karbondioksit emisyonlarının çevreye etkisi ve kontrolü, Mühendis ve Makine, 48(564), 22-26.

Soylu S. (2007), Estimation of Turkish road transport emissions, Energy Policy, 35(8), 4088-4094.

Senel G.U., Atabey T., (2020), Diyarbakır ilinde farklı sektörlerden kaynaklanan karbondioksit salınımının hesaplanması, Kahramanmaraş Sütçü İmam Üniversitesi Mühendislik Bilimleri Dergisi, 23(1), 37-47.

TCDD, (2020a), Demiryolu sektör raporu 2019, https://www.tcdd.gov.tr/files/istatistik/2019faaliyetraporu.pdf, [Erişim 01 Aralık 2020].

TCDD, (2020b), 2015-2019 istatistik yıllığg, https://www.tcdd.gov.tr/files/istatistik//20152019yillik.pdf, [Erişim 01 Aralık 2020]

Timperley J., (2018), Carbon Brief Türkiye Profili, https://www.carbonbrief.org/carbon-brief-turkiye-profili [Erişim 19 Mart 2021].

Tongwane M., Piketh S., Stevens L., Ramotubei T. (2015), Greenhouse gas emissions from road transport in South Africa and Lesotho between 2000 and 2009, Transportation Research Part D: Transport and Environment, 37, 1-13.

TUIK, (2020a), Adrese dayalı nüfus kayıt sistemi, https://biruni.tuik.gov.tr/medas/?kn=95\&locale=tr, [Erişim 07 Aralık 2020].

TUIK, (2020b), Ulaștırma istatistikleri, https://biruni.tuik.gov.tr/medas/?kn=89\&locale=tr, [Erișim 07 Aralık 2020].

TUIK (2021). Sürdürülebilir Kalkınma Göstergeleri 2010-2019, https://data.tuik.gov.tr/Bulten/OpenPdf?p=521DwrW6DuMGzi4wm 8u/PQ6lvPSaxQewkphAEtE3bA411OoLLwoKZdtSoAf1YEgOwJyJAyLpWYa11L9cxMs3h8iEASfCeQpXJ5A0CxKSN3U=, [Erişim 19 Mart 2021].

Türkay M. (2018), Karayolu ulaşımından kaynaklanan sera gazı emisyonunun (karbon ayak izinin) hesaplanması: Eskişehir ili örneği, Yüksek Lisans Tezi, Cumhuriyet Üniversitesi, Sivas. 
TÜSİAD, (2007), Kurumsal yapısı, yasal çerçevesi ve göstergeleriyle ulaştırma sektörü, Yayın No: TÜSİAD-T/2007-02/431, MIKADO MATBAACILIK ve Tic. Ltd. Şti., İstanbul, 61ss.

Yaman A.B., Sevimlioğlu O., (2018). Kocaeli ilinde evsel katı atıkların toplanmasından kaynaklanan sera gazı emisyon hesabı, https://www.researchgate.net/publication/343788935, [Erişim 29 Aralık 2020]

Zhang N., Zhou P., Kung C. (2015), Total-factor carbon emission performance of the Chinese transportation industry: a bootstrapped non-radial Malmquist index analysis, Renewable and Sustainable Energy Reviews, 41, 584-593. 